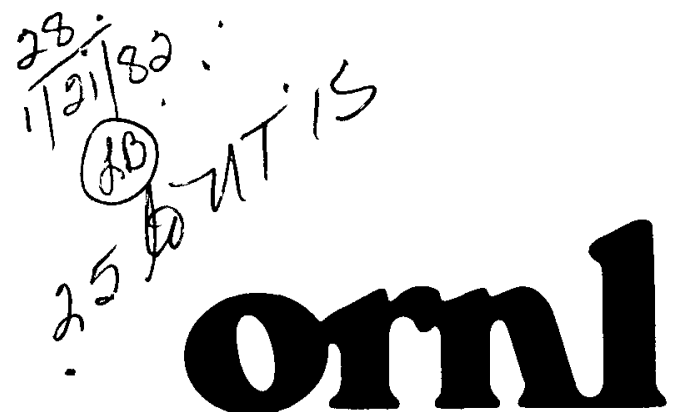

OAK

RIDGE

NATIONAL

LABORATORY

UNION

CARBIDE

$$
\begin{aligned}
& I-926 \\
& \text { MASTIP }
\end{aligned}
$$

\title{
Creep Properties of Forged 2219 T6 Aluminum Alloy Shell of General- Purpose Heat Source-Radioisotope Thermoelectric Generator
}

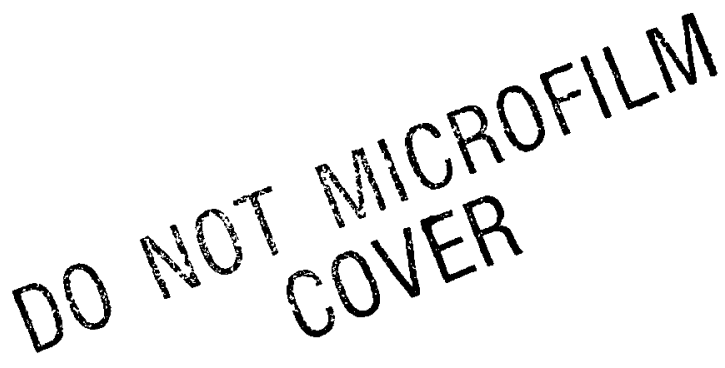

OPERATED BY

UNION CARBIDE CORPORATION FOR THE UNITED STATES DEPARTMENT OF ENERGY

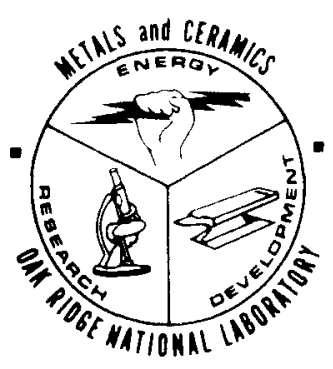




\section{DISCLAIMER}

This report was prepared as an account of work sponsored by an agency of the United States Government. Neither the United States Government nor any agency Thereof, nor any of their employees, makes any warranty, express or implied, or assumes any legal liability or responsibility for the accuracy, completeness, or usefulness of any information, apparatus, product, or process disclosed, or represents that its use would not infringe privately owned rights. Reference herein to any specific commercial product, process, or service by trade name, trademark, manufacturer, or otherwise does not necessarily constitute or imply its endorsement, recommendation, or favoring by the United States Government or any agency thereof. The views and opinions of authors expressed herein do not necessarily state or reflect those of the United States Government or any agency thereof. 


\section{DISCLAIMER}

Portions of this document may be illegible in electronic image products. Images are produced from the best available original document. 


\section{Printed in the United States of America Avaılable from National Technical Information Service \\ US Department of Commerce \\ 5285 Port Royal Road, Springfield, Virginia 22161}

NTIS price codes-Printed Copy A04 Microfiche A01

This report was prepared as an account of work sponsored by an agency of the United States Government Neither the United States Government nor any agency thereof nor any of their employees makes any warranty express or implied or assumes any legal hability or responsibility for the accuracy completeness, or usefulness of any information apparatus product or process disclosed or represents that its use would not infringe privately owned rights Reference herein to any specitic commercial product process or service by trade name trademark. manufacturer or otherwise does not necessarily constitute or imply its ir di semert lecommendatior or favori,g by the United States Government or any dyericy thereof The views and opintons of authors expressed herein do not neressarbly state or reflect those of the United States Government or any agency ireredit 
HOTIGE

ORNL/TM-8020

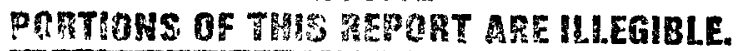

It has been reprobuced frem the best available coping fo parmit the broadest possible availability.

Minotiti

Contract No. W-7405-eng-26

METALS AND CERAMICS DIVISION

CREEP PROPERTIES OF FORGED 2219 T6 ALUMINUM ALLOY SHELL OF GENERALPURPOSE HEAT SOURCE-RADIOISOTOPE THERMOELECTRIC GENERATOR

\title{
J. P. Hammond
}

Date Published: December 1981

NOTICE: This document contains information of a preliminary nature. It is subject to revision or correction and therefore does not represent a final report.

\author{
OAK RIDGE NATIONAL LABORATORY \\ Oak Ridge, Tennessee 37830 \\ operated by \\ UNION CARBIDE CORPORATION \\ $f$ or the \\ DEPARTMENT OF ENERGY
}

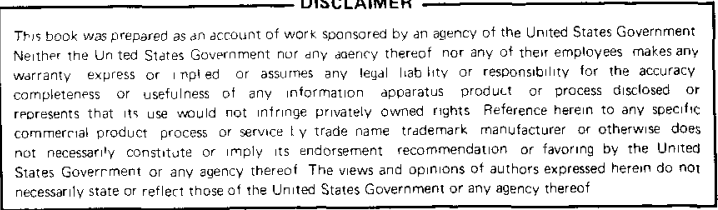


CONTENTS

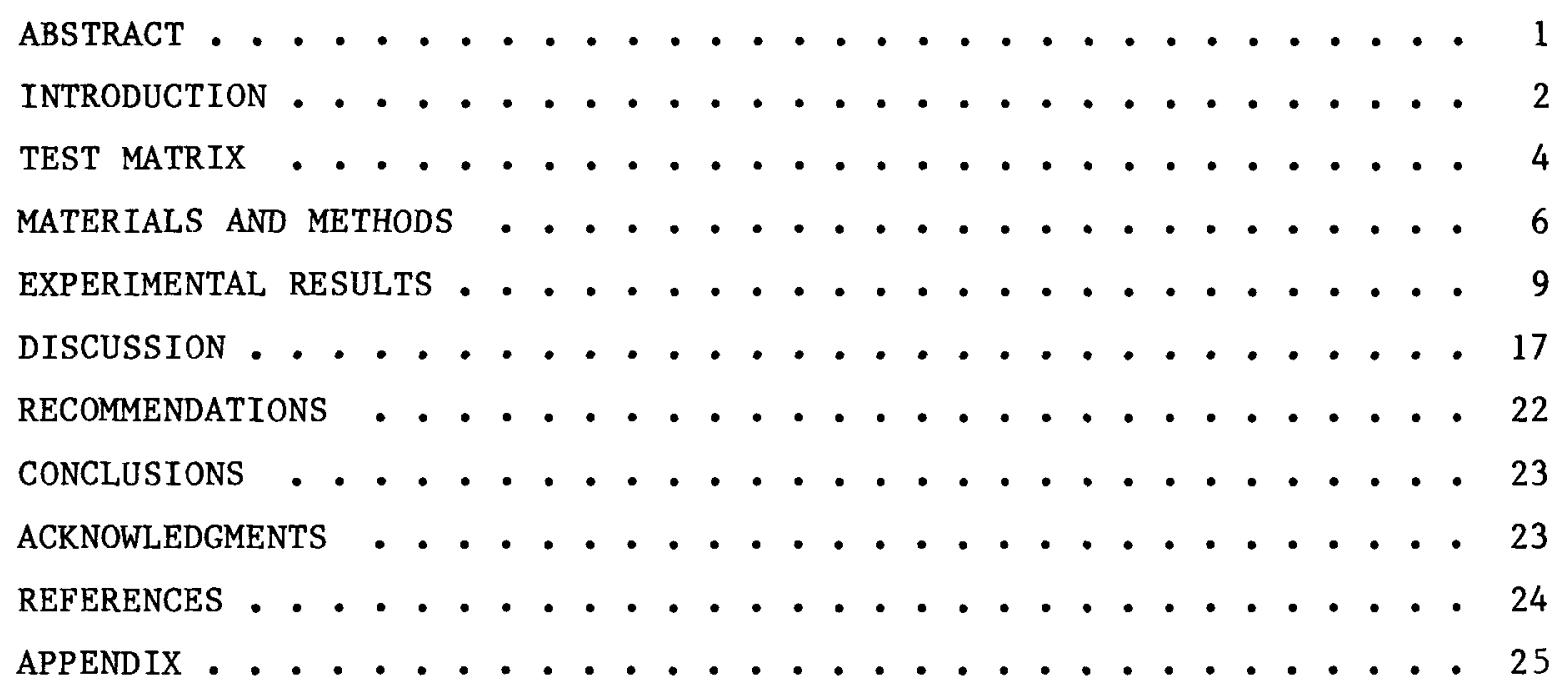


CREEP PROPERTIES OF FORGED 2219 T6 ALUMINUM ALLOY SHELL OF GENERAL PURPOSE HEAT SOURCE-RADIOISOTOPE THERMOELECTRIC GENERATOR

\author{
J. P. Hammond
}

ABSTRACT

The she11 (2219 T6 aluminum forging) of the General Purpose Heat Source-Radioisotope Thermoelectric Generator (GPHS-RTG) was designed to retain the generator under sufficient elastic stress to secure it during space flight. A major concern was the extent to which the elastic stress would relax by creep. To determine acceptability of the shell construction material, proof tests simulating service were performed. These tests included (1) $600 \mathrm{~h}$ of testing at $270^{\circ} \mathrm{C}$ under $24.1 \mathrm{MPa}$ stress followed by $10,000 \mathrm{~h}$ of storage at $177^{\circ} \mathrm{C}$ under $55.1 \mathrm{MPa}$, both on the ground and (2) $10,000 \mathrm{~h}$ of flight in space at $270^{\circ} \mathrm{C}$ under $34.4 \mathrm{MPa}$ stress. Additionally, systematic creep testing was performed at 177 and $260^{\circ} \mathrm{C}$ to establish creep design curves (stress-time relationships for 0.1 and $0.2 \%$ total creep and stress - minimumcreep-rate $\dot{\varepsilon}_{m}$ relationships).

The creep tests performed on 2219 T6 at $177^{\circ} \mathrm{C}$ revealed comparatively large amounts of primary creep followed by small amounts of secondary creep. The early creep is believed to be abetted by unstable substructures that are annealed out during testing at this temperature. The $\dot{\varepsilon}_{m}$ values at this temperature increased from $1.9 \times 10^{-6 \% / \mathrm{h}}$ at $27.6 \mathrm{MPa}$ stress to $4.0 \times 10^{-6 \% / \mathrm{h}}$ at $48.3 \mathrm{MPa}$.

The creep tests performed at $260^{\circ} \mathrm{C}$ showed normal primary creep followed by large amounts of secondary creep. The $\dot{\varepsilon}_{m}$ values increased from $1.3 \times 10^{-5} \% / \mathrm{h}$ at $26.2 \mathrm{MPa}$ to $2.1 \times 10^{-4} \% / \mathrm{h}$ at $65.5 \mathrm{MPa}$.

Duplicate proof tests simulating the ground exposure conditions gave results that were in good agreement. The $\dot{\varepsilon}_{m}$ values at $177^{\circ} \mathrm{C}$ were $3.25 \times 10^{-6}$ and $3.75 \times 10^{-6 \% / h}$, which amount to an average of less than $0.04 \%$ creep in $10,000 \mathrm{~h}$. The primary creep is not of great concern because it can be largely offset by operational and design features.

The proof test that simulates space flight at $270^{\circ} \mathrm{C}$ gave $0.11 \%$ primary creep followed by $0.59 \%$ secondary creep. About $10 \%$ of the second-stage creep was caused by four or five instantaneous strains, called "strain bursts," which began at the 4500-h mark.

One or two strain bursts, which measured 0.01 to $0.02 \%$, occurred in each of several other tests at 177 and $260^{\circ} \mathrm{C}$ but were assessed as very moderate in magnitude. The effect is attributable to a slightly microsegregated condition remaining from the original cast structure. 
INTRODUCTION

The objective of this program is to provide long-term creep test data for the aluminum outer shell (2219 T6 aluminum forging) of the General Purpose Heat Source-Radioisotope Thermoelectric Generator (GPHS-RTG), an electric power supply for spacecraft. The essential requirement of the shell is to retain the RTG firmly under elastic stress during ground tests and storage in air (condition II) and during subsequent flight in space (condition I).

The aluminum 2219 T6 alloy, as a forging, was selected as the construction material for the shell because of its favorable strength-toweight ratio. Between 204 and $260^{\circ} \mathrm{C}, 2219 \mathrm{~T} 6$ shows the best combination of tensile and creep-rupture strength of all the aluminum alloys. 1 In addition, it has excellent weldability by the gas, arc, or resistance processes. However, the current application involves service in excess of $20,000 \mathrm{~h}$ at elevated temperature, and the literature showed that the available creep data on the 2219 alloy scarcely exceeded $1000 \mathrm{~h}$.

A cutaway drawing of the GPHS-RTG is shown in Fig. 1 (ref. 2) The heat source assembly consists of 18 rectangular modules held together by a longitudinal compressive preload applied by spring-loaded frames at each end. The longitudinal preloads are reacted out by the aluminum outer shell assembly. Lateral support at the midspan of the heat source assembly is provided by four radial spring-loaded pins. The preload from these pins is reacted out by the midspan ring of the aluminum outer shell assembly. The support system is shown schematically in Fig. 2 (ref. 2). Because of thermal expansion of the aluminum shell relative to the heat source and its support system, the longitudinal and radial preloads change during different phases of assembly test, storage, and flight. Should excessive creep occur in the aluminum she11, the spring-loaded heat source support system would relax the preloads and thereby make inadequate the support of the heat source assembly.

During the manufacturing cycle, the RTG outer case will be stress relieved at about $177^{\circ} \mathrm{C}$. The case will then receive an emissivity coating, which will be baked at about $260^{\circ} \mathrm{C}$ for $100 \mathrm{~h}$. 


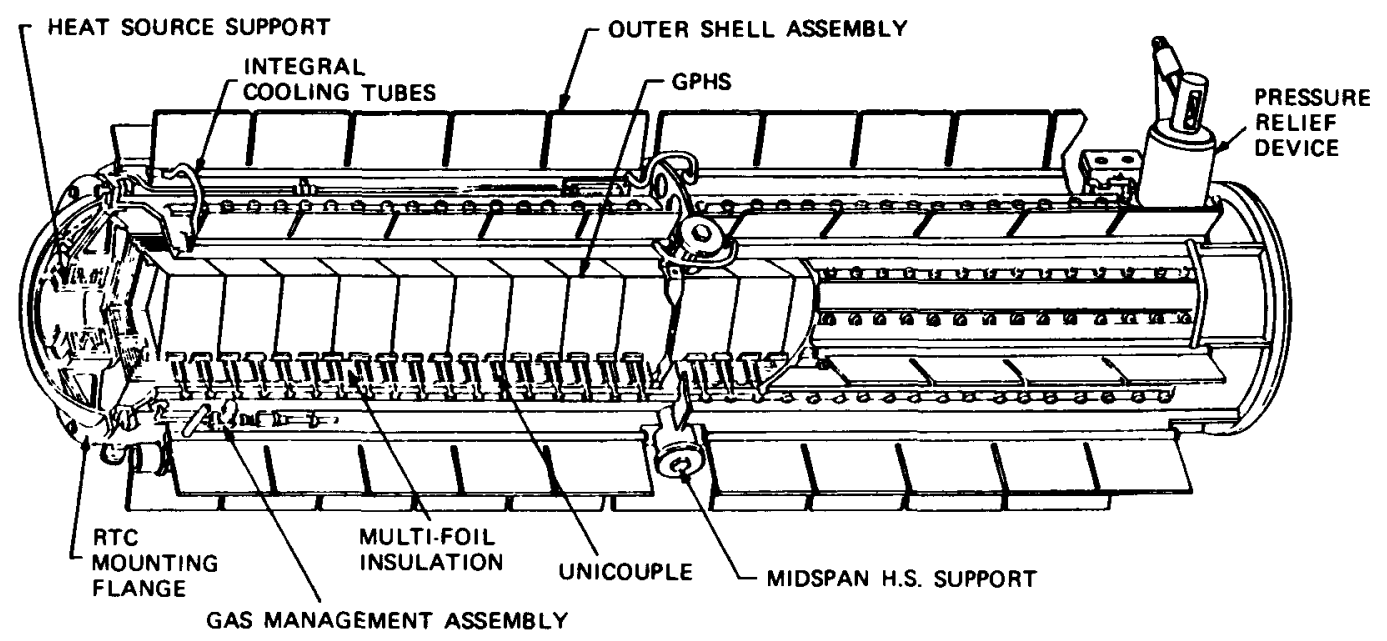

Fig. 1. Assembly drawing of General Purpose Heat Source-Radioisotope Thermoelectric Generator. Courtesy of General Electric Company, King of Prussia, $\mathrm{Pa}$.

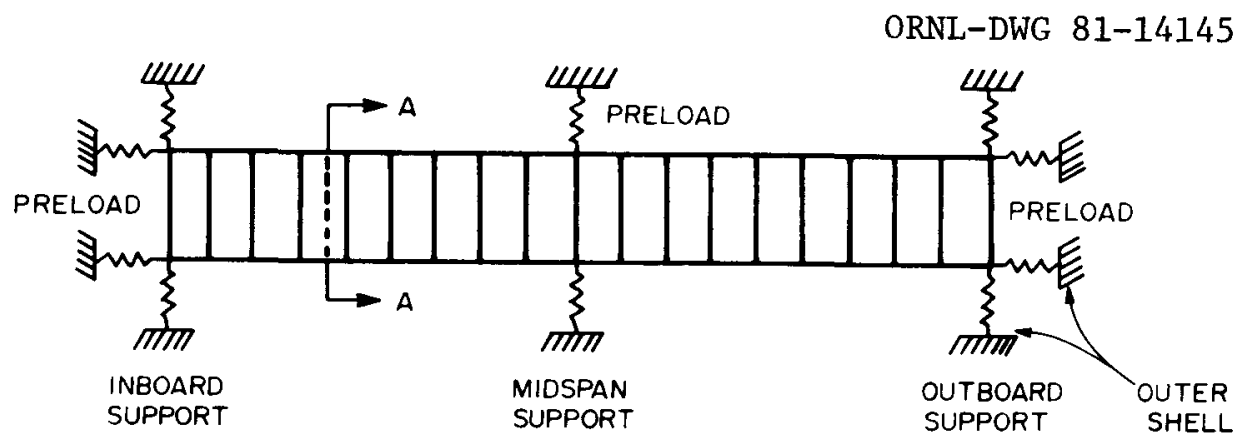

EFFECTIVE STRUCTURAL LOAD PATHS IN GPHS MODULE.

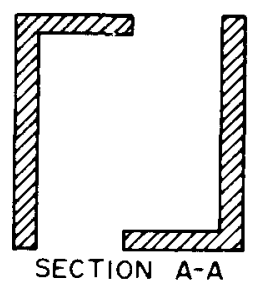

Fig. 2. Heat source assembly support system. 
Following assembly of an RTG, the case will experience maximum temperatures of about $270^{\circ} \mathrm{C}$ for an estimated $600 \mathrm{~h}$ under vacuum. This period includes processing and acceptance testing. The RTG will then be placed in storage with a maximum case temperature of about $177^{\circ} \mathrm{C}$ for an estimated $10,000 \mathrm{~h}$. The RTG will then be launched, and the case will be subjected to a maximum temperature of $270^{\circ} \mathrm{C}$ for the duration of the mission. During vacuum operation and storage, the outer shell will be subjected to stresses from application of the internal preload to the heat source assembly.

\section{TEST MATRIX}

In collaboration with representatives of the General Electric Company, Valley Forge, Pennsylvania, the test matrix was developed for determining the creep strain in the aluminum shel1 under service conditions. Analysis of the creep results gave elongations in the shell that were within permitted limits, as shown in Table 1.

Table 1. Predicted creep in Radioisotope Thermoelectric Generator outer shell

\begin{tabular}{llcc}
\hline \multirow{2}{*}{ Direction } & \multicolumn{2}{c}{ Deformation } & Launch preload \\
\cline { 2 - 3 } & $(\mathrm{cm})$ & $($ in. $)$ & $(\%)$ \\
\hline Longitudinal & 0.079 & 0.031 & 13 \\
Radial & 0.010 & 0.004 & 12 \\
\hline
\end{tabular}

Preload design margin $=25 \%$.

The test matrix is presented in Table 2. The matrix calls for two proof tests to determine creep strain under the most intense stresstemperature conditions envisioned for the shell during the 10,000-h flight in space at $270^{\circ} \mathrm{C}$ (test I, Table 1) and the combined ground test at $270^{\circ} \mathrm{C}$ and $10,000-\mathrm{h}$ storage at $177^{\circ} \mathrm{C}$ (test II). To save time, these tests were performed separately rather than in tandem on the same specimen (test II followed by $I$ ). In interpreting results, we invoked the life fraction rule. 3 
Table 2. Creep test matrix of 2219 T6 alloy forging

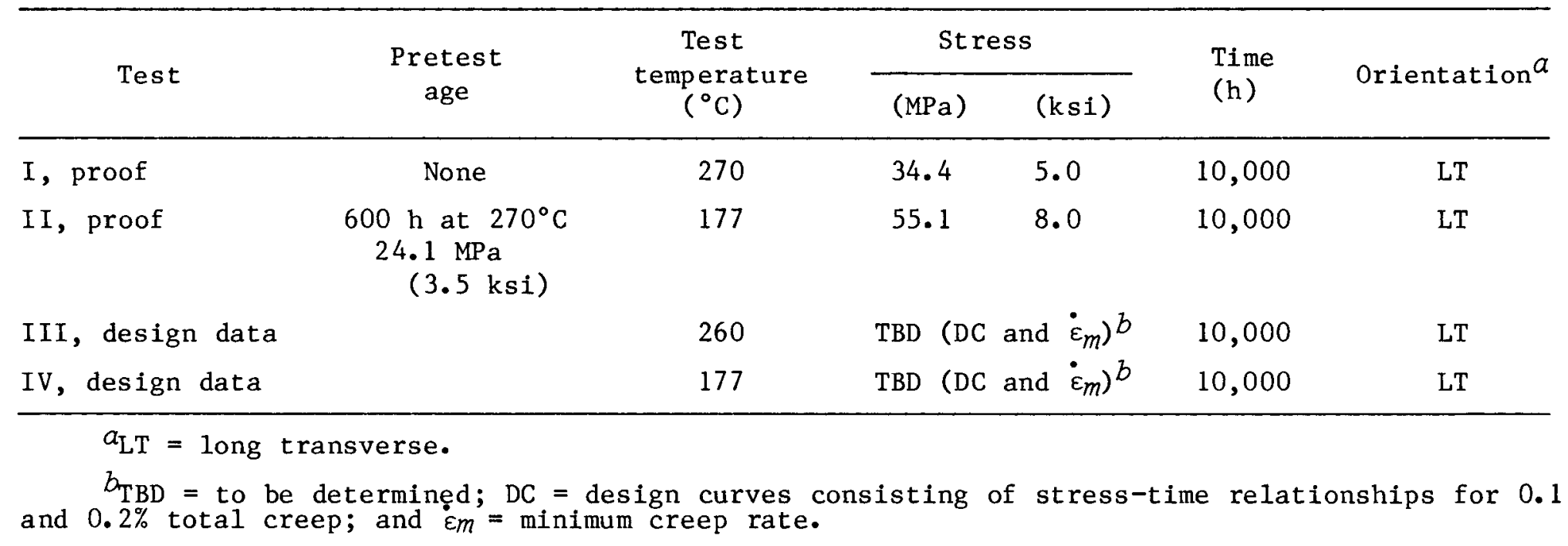


This principle states that the amount of creep and the fraction of rupture life used up under one set of service conditions is independent of previous conditions and that the effects of exposure under the separate conditions are cumulative. However, this rule generally is not valid if conditions are severe enough to promote significant microstructural changes in the metal, and results obtained from separate tests should be checked with a single inclusive test (as time permits).

To aid in assessing cumulative plastic strain in the she11, design curves establishing the stress-time relationships for 0.1 and $0.2 \%$ creep at 260 and $177^{\circ} \mathrm{C}$ were determined. Because we expected that the design could preclude a large share of the primary (first stage) creep, the relationships between minimum creep rate and stress at 260 and $177^{\circ} \mathrm{C}$ were determined to permit computation of strains from secondary creep projected to stresses and times of loading.

MATERIALS AND METHODS

Creep specimens for the tests were machined from the end-cropping of the 2219 T6 forging from which two RTG shells were to be fabricated by the General Electric Company. The forging was $32 \mathrm{~cm}$ in diameter and $244 \mathrm{~cm}$ long, having been worked down from a $38 \times 64 \times 116 \mathrm{~cm}$ cast ingot. It was purchased from Webber Metals of Paramount, California, under specification QQ-A-367H. The chemical analysis, which meets specification requirements, is

Composition of 2219 Al melt No. K-60-303, wt \%

\begin{tabular}{cccccccc}
$\mathrm{Si}$ & $\mathrm{Fe}$ & $\mathrm{Cu}$ & $\mathrm{Mn}$ & $\mathrm{Mg}$ & $\mathrm{Zn}$ & $\mathrm{Ti}$ & $\mathrm{Zr}$ \\
\hline 0.08 & 0.15 & 6.09 & 0.32 & 0.01 & 0.02 & 0.06 & 0.13
\end{tabular}

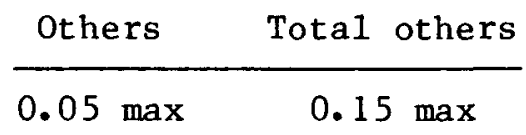


After drilling a 20.3-cm-diam hole through the axis of the forging, the following conventional heat treatment was performed.

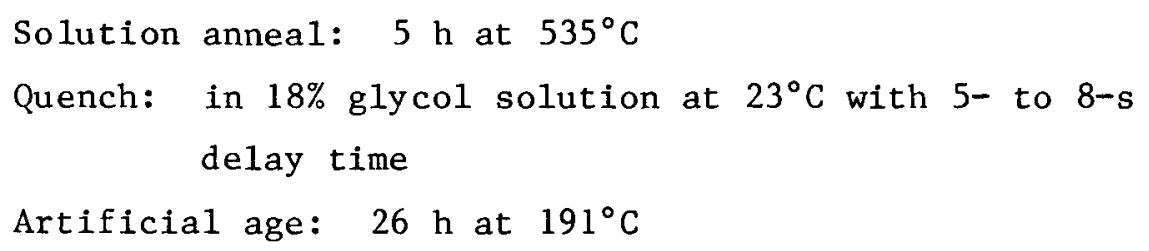

Because the forging had such large dimensions and therefore contained less mechanical fibering than usual, the purchaser placed less stringent strength requirements on the material in the longitudinal direction than required by specification $\mathrm{QQ}-\mathrm{A}-367 \mathrm{H}$. The room-temperature tensile properties measured on the forging in the three principal directions are compared with the specification and purchaser's requirements in Table 3. Although measured properties meet the purchaser's requirements, they fall significantly below those of the specification in the longitudinal direction.

Blanks were taken from the central region of the cropping of the drilled forging, both in the long-transverse (tangential) and longitudinal directions, and creep specimens with a $0.63-\mathrm{cm}$-diam by $3.2-\mathrm{cm}-1$ ength gage were machined in accordance with the requirements of the specimen drawing in Fig. 3.

Creep testing was performed in air with standard lever-arm machines having lever ratios of $6 / 1$ to $12 / 1$. The test methods used exceeded the requirements ${ }^{4}$ of ASTM E 139-70. The creep machines were calibrated to a load accuracy of $\pm 0.5 \%$. Temperature was measured by three Chrome1-Alume 1 thermocouples $( \pm 3 / 8 \%$ accuracy) wired to the gage section. The temperature variation of the gage was less than $\pm 1.0^{\circ} \mathrm{C}$, and the highest temperature (central) was taken as the nominal test temperature. Proportioning temperature controllers were used to maintain the temperatures of the furnaces to $\pm 1.0^{\circ} \mathrm{C}$.

Creep measurements were made with a double (large) dial gage extensometer (Fig. 4). This extensometer averages strain between two measurements and corrects for errors from nominal specimen bending. Strain is measured to an accuracy of $\pm 2.5 \mu \mathrm{m}$ (0.0001 in.). 
Table 3. Room-temperature tensile properties of 2219 T6 aluminum forging

\begin{tabular}{|c|c|c|c|c|c|}
\hline & \multicolumn{2}{|c|}{$\begin{array}{l}\text { U1timate tensile } \\
\text { strength }\end{array}$} & \multicolumn{2}{|c|}{ Yield strength } & \multirow{2}{*}{$\underset{(\%)}{\text { Elongation }}$} \\
\hline & (MPa) & (ksi) & (MPa) & (ksi) & \\
\hline \multicolumn{6}{|c|}{ Longitudinal } \\
\hline Measured & 378 & 54.8 & 259 & 37.5 & 11.0 \\
\hline $\begin{array}{l}\text { Required by } \\
\text { purchaser }\end{array}$ & 372 & 54.0 & 248 & 36.0 & \\
\hline $\begin{array}{l}\text { Required by } \\
\text { specification } \\
\text { QQ-A-367H }\end{array}$ & 400 & 58.0 & 276 & 40.0 & \\
\hline \multicolumn{6}{|c|}{ Tangential } \\
\hline Measured & 383 & 55.5 & 262 & 38.0 & 6.4 \\
\hline $\begin{array}{l}\text { Required by } \\
\text { purchaser }\end{array}$ & 379 & 55.0 & 255 & 37.0 & \\
\hline $\begin{array}{l}\text { Required by } \\
\text { specification } \\
\text { QQ-A-367H }\end{array}$ & 379 & 55.0 & 255 & 37.0 & \\
\hline \multicolumn{6}{|c|}{ Radial } \\
\hline Measured & 363 & 52.7 & 241 & 35.0 & \\
\hline $\begin{array}{l}\text { Required by } \\
\text { purchaser }\end{array}$ & 359 & 52.0 & 241 & 35.0 & \\
\hline $\begin{array}{l}\text { Required by } \\
\text { specification } \\
Q Q-A-367 \mathrm{H}\end{array}$ & 365 & 53.0 & 241 & 35.0 & \\
\hline
\end{tabular}

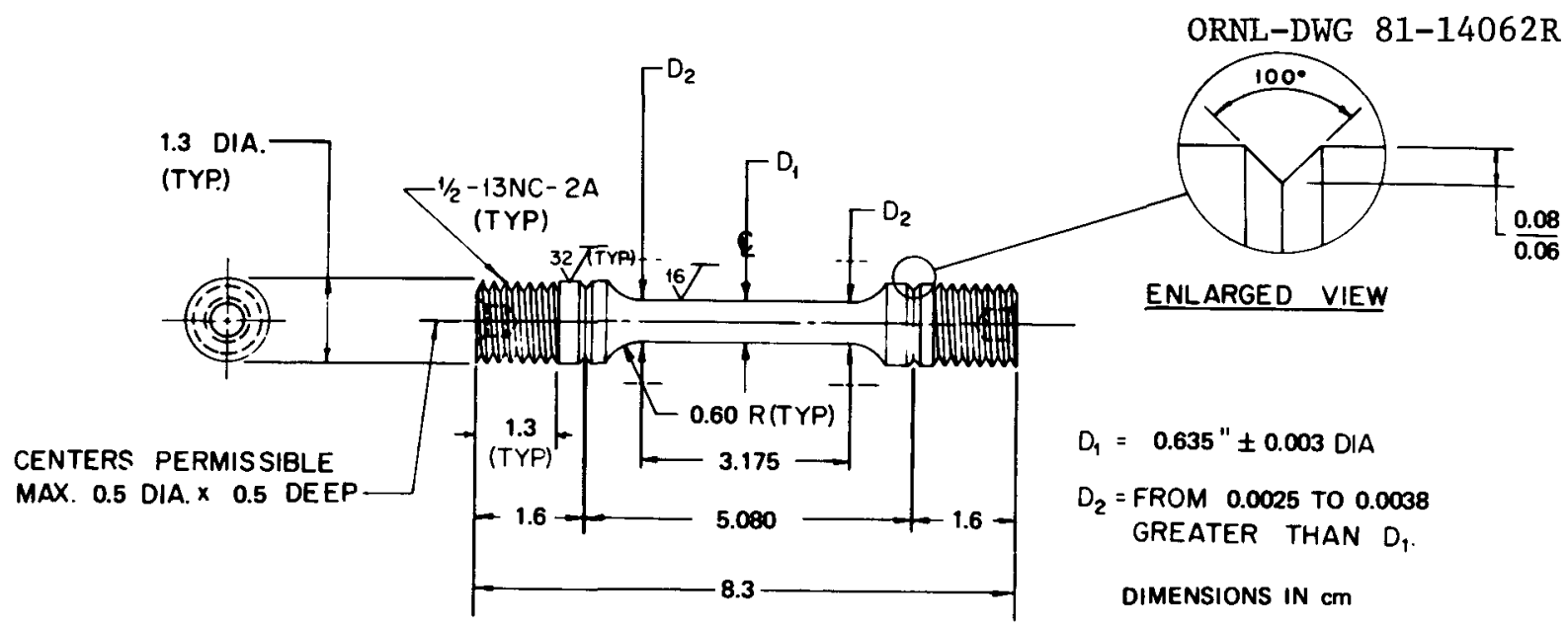

Fig. 3. Creep test specimen. 


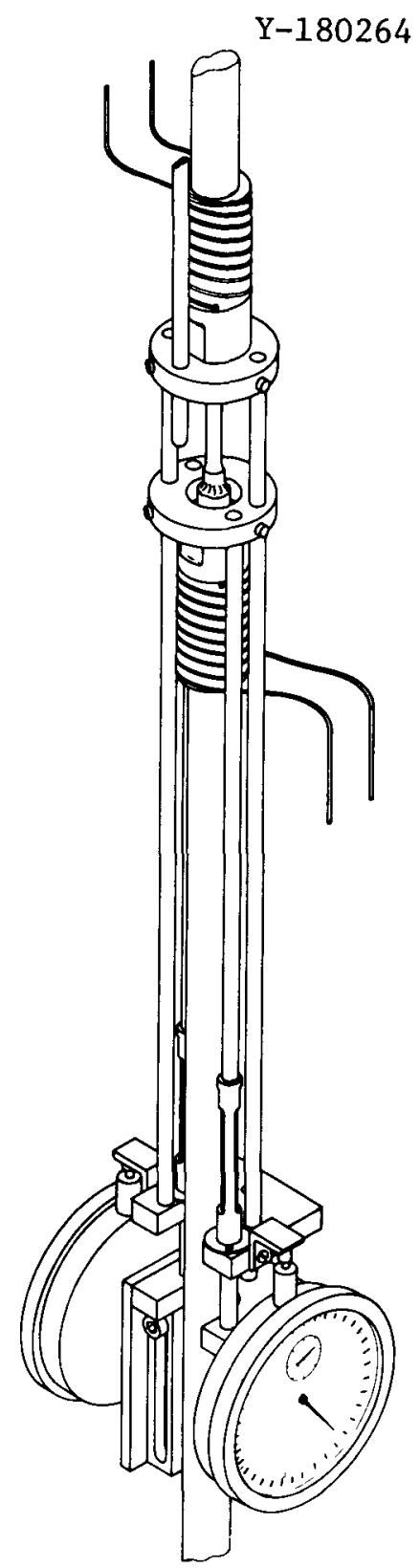

Fig. 4. Dual-dial gage extensometer.

EXPERIMENTAL RESULTS

Results of the creep tests performed on the 2219 T6 forging are summarized in Table 4. Total creep strains $\varepsilon_{p}$ for time in test $t$ are given along with the constant rate of secondary creep $\dot{\varepsilon}_{m}$. Several of the tests either failed or were discontinued to make creep frames available for additional tests. The individual computer readout creep curves with incidental computations for these tests are presented in the Appendix. 
Table 4. Results of creep test ${ }^{a}$ on 2219 T6 alloy forging

\begin{tabular}{|c|c|c|c|c|c|c|c|c|c|}
\hline \multirow{2}{*}{ Test } & \multirow{2}{*}{ Specimen $b$} & \multicolumn{2}{|c|}{ Temperature } & \multicolumn{2}{|c|}{ Stress } & \multirow{2}{*}{$\underset{(\%)}{\text { Creep }} \dot{\varepsilon}_{p}$} & \multirow{2}{*}{$\begin{array}{c}\text { Time } \\
(h)\end{array}$} & \multirow{2}{*}{$\begin{array}{l}\text { Rate } \dot{\varepsilon}_{m} \\
(\% / \mathrm{h})\end{array}$} & \multirow{2}{*}{ Status } \\
\hline & & $\left({ }^{\circ} \mathrm{C}\right)$ & $\left({ }^{\circ} \mathrm{F}\right)$ & (MPa) & (ksi) & & & & \\
\hline I, proof & LT-11 & 270 & 518 & 34.4 & 5.0 & 0.681 & 9276 & $4.5 \times 10^{-5}$ & Running \\
\hline II, proof A & $\begin{array}{l}\text { LT-6 } \\
\text { LT-6 }\end{array}$ & $\begin{array}{l}270 \\
177\end{array}$ & $\begin{array}{l}518 \\
350\end{array}$ & $\begin{array}{l}24.1 \\
55.1\end{array}$ & $\begin{array}{l}3.5 \\
8.0\end{array}$ & $\begin{array}{l}0.084 \\
0.057\end{array}$ & $\begin{array}{r}597 \\
9237\end{array}$ & $\frac{c}{3.25 \times 10^{-6}}$ & Running \\
\hline II, proof B & $\begin{array}{l}\text { LT- } 16 \\
\text { LT-16 }\end{array}$ & $\begin{array}{l}270 \\
170\end{array}$ & $\begin{array}{l}518 \\
350\end{array}$ & $\begin{array}{l}24.1 \\
55.1\end{array}$ & $\begin{array}{l}3.5 \\
8.0\end{array}$ & $\begin{array}{l}0.063 \\
0.060\end{array}$ & $\begin{array}{r}645 \\
3788\end{array}$ & $\frac{c}{3.75 \times 10^{-6}}$ & Running \\
\hline III, design & $\mathrm{LT}-7$ & 260 & 500 & 65.5 & 9.5 & 0.384 & 979 & $2.15 \times 10^{-4}$ & Discontinued \\
\hline III, design & $\mathrm{LT}-12$ & 260 & 500 & 56.5 & 8.2 & 0.497 & 2600 & $1.04 \times 10^{-4}$ & Failed \\
\hline III, design & $\mathrm{LT}-17$ & 260 & 500 & 53.1 & 7.7 & 0.870 & 4065 & $1.44 \times 10^{-4}$ & Failed \\
\hline III, design & LT-9 & 260 & 500 & 41.4 & 6.0 & 0.442 & 8454 & $3.7 \times 10^{-5}$ & Running \\
\hline III, design & $\mathrm{LT}-14$ & 260 & 500 & 34.5 & 5.0 & 0.116 & 4799 & $2.18 \times 10^{-5}$ & Discontinued \\
\hline III, design & $\mathrm{T}-1$ & 260 & 500 & 26.2 & 3.8 & 0.213 & 5652 & $1.3 \times 10^{-5}$ & Running \\
\hline IV, design & $\mathrm{LT}-8$ & 177 & 350 & 48.3 & 7.0 & 0.243 & 8586 & $4.0 \times 10^{-6}$ & Running \\
\hline IV, design & LT-13 & 177 & 350 & 40.0 & 5.8 & 0.135 & 7614 & $4.0 \times 10^{-6}$ & Running \\
\hline IV, design & LT- 18 & 177 & 350 & 31.7 & 4.6 & 0.105 & 4372 & $2.0 \times 10^{-6}$ & Discontinued \\
\hline IV, design & $\mathrm{T}-2$ & 177 & 350 & 27.6 & 4.0 & 0.226 & 4410 & $1.9 \times 10^{-6}$ & Running \\
\hline Preliminary & $\mathrm{L}-1$ & 260 & 500 & 65.5 & 9.5 & 0.154 & 1026 & $4.6 \times 10^{-5}$ & Discontinued \\
\hline Preliminary & $\mathrm{L}-2$ & 177 & 350 & 55.1 & 8.0 & 0.221 & 1145 & $1.5 \times 10^{-5}$ & Discontinued \\
\hline
\end{tabular}

$a_{\text {Conducted in air. }}$

$b_{\mathrm{LT}}=$ long transverse orientation; $\mathrm{L}=$ longitudinal.

$c_{\text {In }}$ primary creep stage. 
The creep curve for proof test $I$ is shown in Fig. 5, and Figs. 6 and 7 give the curves for duplicate runs of proof test II. The stages of creep response are marked on the graphs along with computations of $\varepsilon_{m}$. Proof test I $\left(10,000-\mathrm{h}\right.$ space flight at $270^{\circ} \mathrm{C}$ and $34.4 \mathrm{MPa}$ stress) shows a primary stage of creep from $A$ to $B$ and secondary creep from $B$ to $C$, for which the constant rate of creep is $4.5 \times 10^{-5 \%} / \mathrm{h}$. At this rate of creep, the total strain from secondary creep after $10,000 \mathrm{~h}$ would be $0.45 \%$, and, when added to the primary creep, the total creep would be $0.56 \%$.

However, after about $4500 \mathrm{~h}$, the curve shows three small strain of $\mathrm{f}-$ sets (at C, D, and E) before exhibiting a segment of somewhat increased slope (EF). Still a fourth distinct of fset is seen at F, seemingly followed by another straight segment (FG) of slope slightly increased over that of EF. The test has gone $9276 \mathrm{~h}$ and given a total creep strain of $0.68 \%$. With the current rate of creep and barring additional strain offsets, the creep after $10,000 \mathrm{~h}$ would be about $0.76 \%$. This is to be compared with the strain of $0.56 \%$ had the test continued at the initial constant creep rate and not incurred the unpredictable strain offsets and inflections upward.

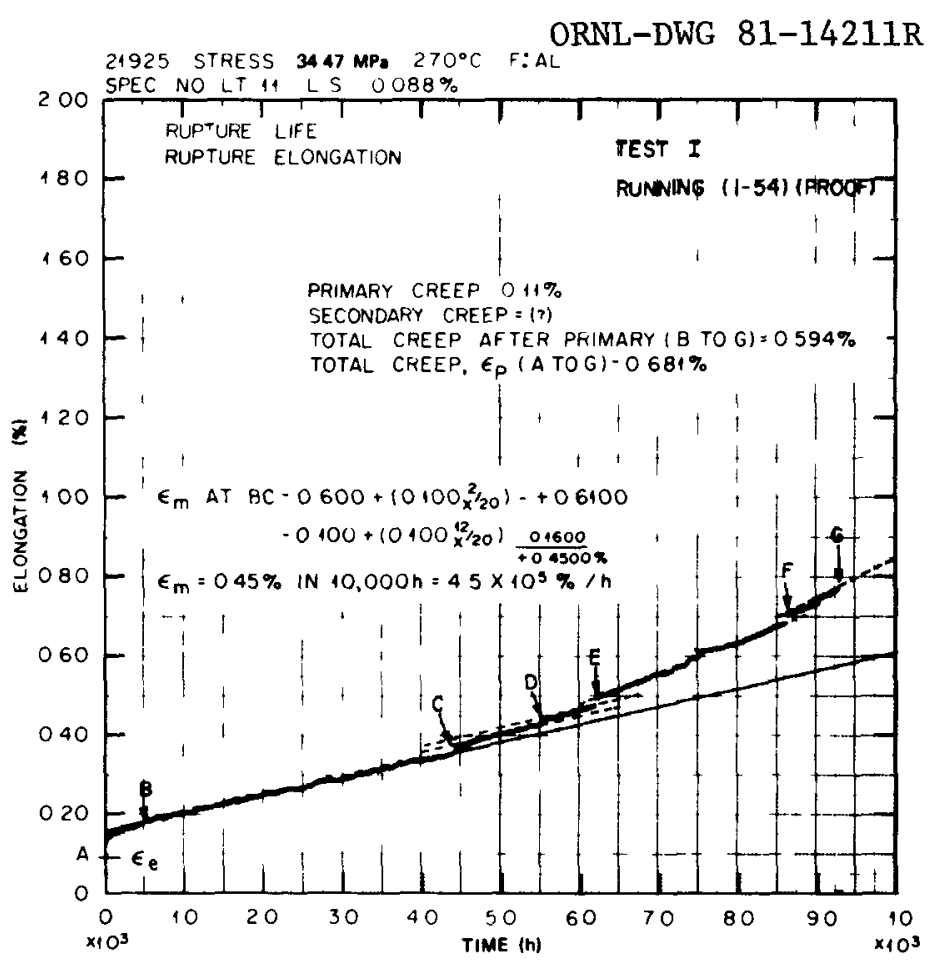

Fig. 5. Creep curve for proof test I (space flight). 


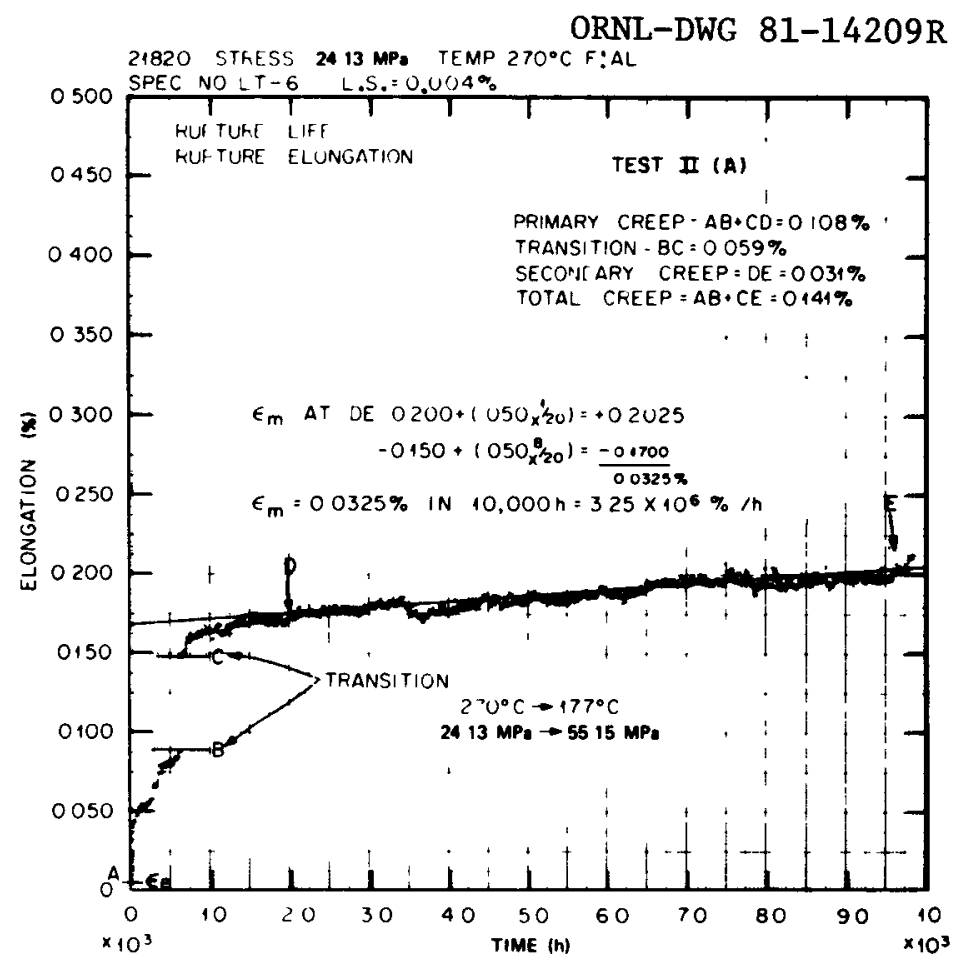

Fig. 6. Creep curve for proof test II [ground test (AB) and storage (CDE)]

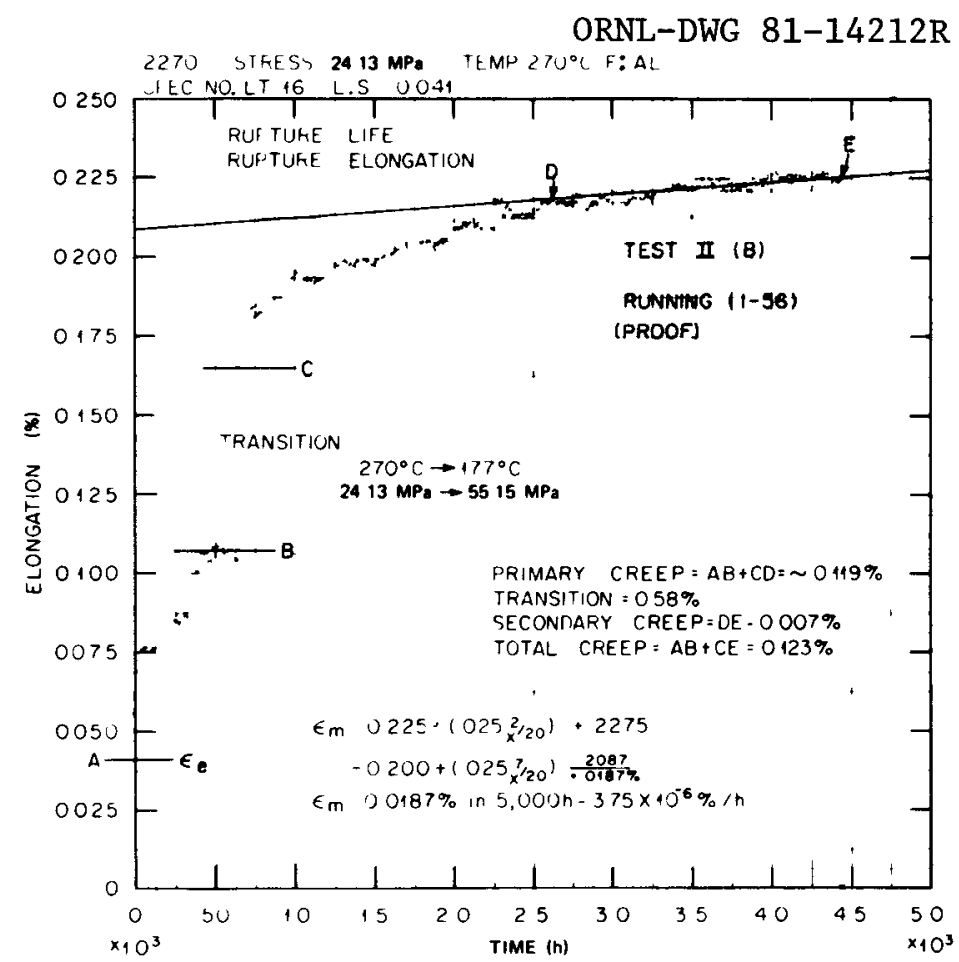

Fig. 7. Creep curve for duplicate of proof test II. 
The observed offsets occurred in several of the other creep tests both at 260 and $177^{\circ} \mathrm{C}$, and, because they possibly could contribute significantly to the total creep relaxation of stress in the RTG shell, they will be discussed in more detail subsequently. The phenomenon is not a common one and is referred to in the literature as creep bursts 5,6 or jumps. 7 Such strain bursts are usually associated with weld ${ }^{5}$ or cast $^{6}$ structures.

The first of the two proof tests II $\left(600-\mathrm{h}\right.$ pretest age at $270^{\circ} \mathrm{C}$ and $24.1 \mathrm{MPa}$ followed by $10,000-\mathrm{h}$ ground storage at $177^{\circ} \mathrm{C}$ and $55.1 \mathrm{MPa}$ ) $\operatorname{logged}$ in $9237 \mathrm{~h}$ of storage (Table 2), and results of the test now appear to be predictable. The projected creep strain for the completed test is $0.136 \%$ (Table 2). Region A-B in Fig. 6 represents the creep response during onground aging, B-C shows the strain sustained from taking the tests from aging to storage, and $C-D-E$ gives the creep response during the first $9237 \mathrm{~h}$ of storage. The strain from A to D in Fig. 6 is essentially primary creep, and D-E is steady state, for which $\dot{\varepsilon}_{m}$ is only $3.25 \times 10^{-6 \% / h}$. It is significant that the earlier aging $(A-B)$ dissipates the bulk of the primary creep and leaves only about $0.025 \%$ (C-D) to be dissipated during storage. Also, the minimum creep rate during storage (DE in Fig. 6) is very low, giving a projected secondary creep of only $0.033 \%$ in $10,000 \mathrm{~h}$.

The duplicate of proof test II gave a curve (Fig. 7) closely conforming to the earlier one. Although this test went only $3788 \mathrm{~h}$ into storage, its secondary creep rate $\left(3.75 \times 10^{-6 \% / h}\right)$ is very close to that of test IIA. The transition strain $\mathrm{B}-\mathrm{C}$ was $0.58 \%$ compared with $0.59 \%$ for the earlier test. Thus, barring effects from any future strain bursts in test IIB, the test appears to be reproducible.

Design curves of the relationships of stress and time to 0.1 and $0.2 \%$ total creep at $260^{\circ} \mathrm{C}$ (test III of Table 2) are presented in Fig. 8. The individual creep graphs on which the design curves are based are given in the Appendix, tests LT-7 through T-1. The design curves suggest that, for $10,000 \mathrm{~h}$, a stress of about $29.0 \mathrm{MPa}$ would be required to produce $0.1 \%$ creep strain and that a stress of $35.8 \mathrm{MPa}$ would be needed to produce $0.2 \%$ creep. However, the LT-14 data point for $0.2 \%$ strain is based on an extrapolation from data to about $5000 \mathrm{~h}$; in view of the strain bursts and inflections cited earlier for proof test II $\left(270^{\circ} \mathrm{C}\right)$, the validity of the 


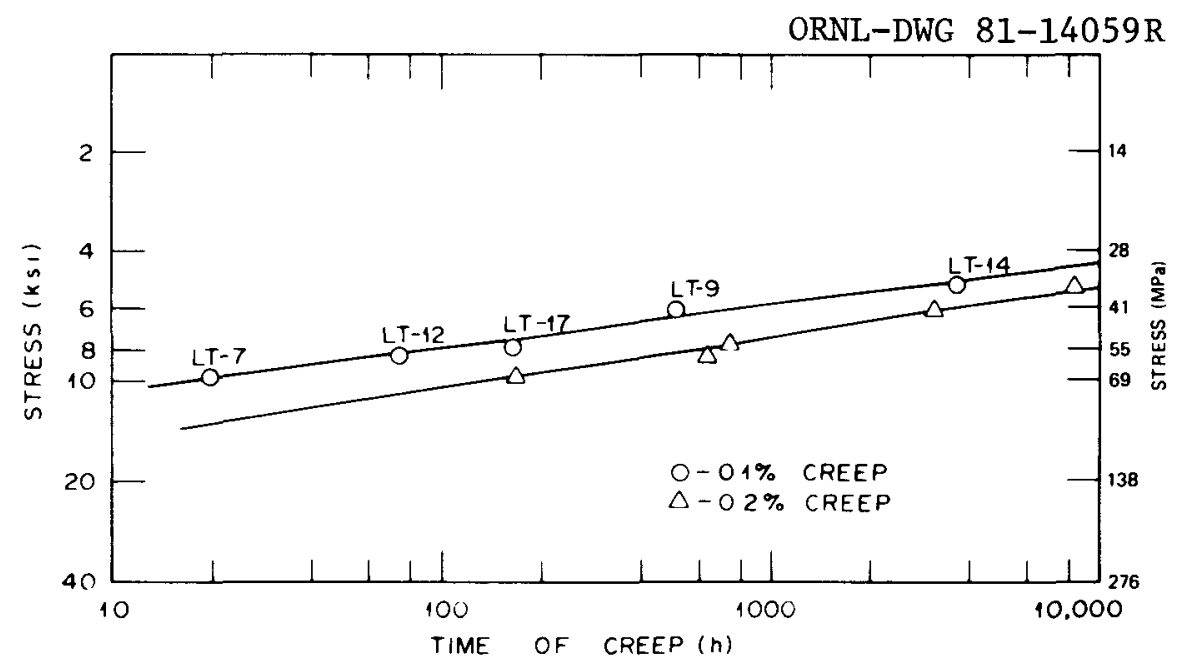

Fig. 8. Design curves of 2219 T6 forging showing stress-time relationship for 0.1 and $0.2 \%$ creep at $260^{\circ} \mathrm{C}$.

right portion of the $0.2 \%$ graph perhaps should be held in abeyance until longer time is accrued for LT-14. So far, the only evidence for possible strain bursts in the $260^{\circ} \mathrm{C}$ tests appeared in the LT-9 and T-1 tests at times of about 7500 and $5000 \mathrm{~h}$, respectively (see Appendix).

In Fig. 9 data showing the relationship between stress and minimum creep rate are plotted for the tests at $260^{\circ} \mathrm{C}$. The data point obtained from proof test I at $270^{\circ} \mathrm{C}(\mathrm{LT}-11)$ is included. Because such data plotted on a $\log -\log$ graph frequently give a straight line, they are so represented in this figure. The data show very little scatter. By extrapolation to lower stresses, these results suggest that, at $260^{\circ} \mathrm{C}$, a stress of $31.0 \mathrm{MPa}$ would be required to produce $0.2 \%$ strain by secondary creep and a stress of $24.8 \mathrm{MPa}$ to give $0.1 \%$ strain.

The stress-time relationship to produce $0.1 \%$ total creep and the relationship between stress and minimum creep rate for the tests performed at $177^{\circ} \mathrm{C}$ are presented in Figs. 10 and 11 , respectively. The data for creep tests performed at $260^{\circ} \mathrm{C}$ are included for comparison. Incidents of strain burst at $177^{\circ} \mathrm{C}$ occurred for test LT-13 and T-1 (see Appendix).

As a result of the extremely low minimum creep rates for the tests conducted at $177^{\circ} \mathrm{C}\left(1.9\right.$ to $\left.4.0 \times 10^{-6 \% / h}\right)$, the creep curves usually failed to extrapolate to total strains of $0.2 \%$ within $10,000 \mathrm{~h}$. As a result, the 
$0.2 \%$ strain design curve is not given for the $177^{\circ} \mathrm{C}$ temperature. Also, because the amount of primary creep at $177^{\circ} \mathrm{C}$ appeared to be somewhat greater and to occur at a faster rate than at $260^{\circ} \mathrm{C}$, the design curve for $0.1 \%$ strain at $177^{\circ} \mathrm{C}$ fell in a region of lower stress than did the $0.1 \%$ curve at $260^{\circ} \mathrm{C}$. This (illustrated in Fig. 10) was most unexpected.

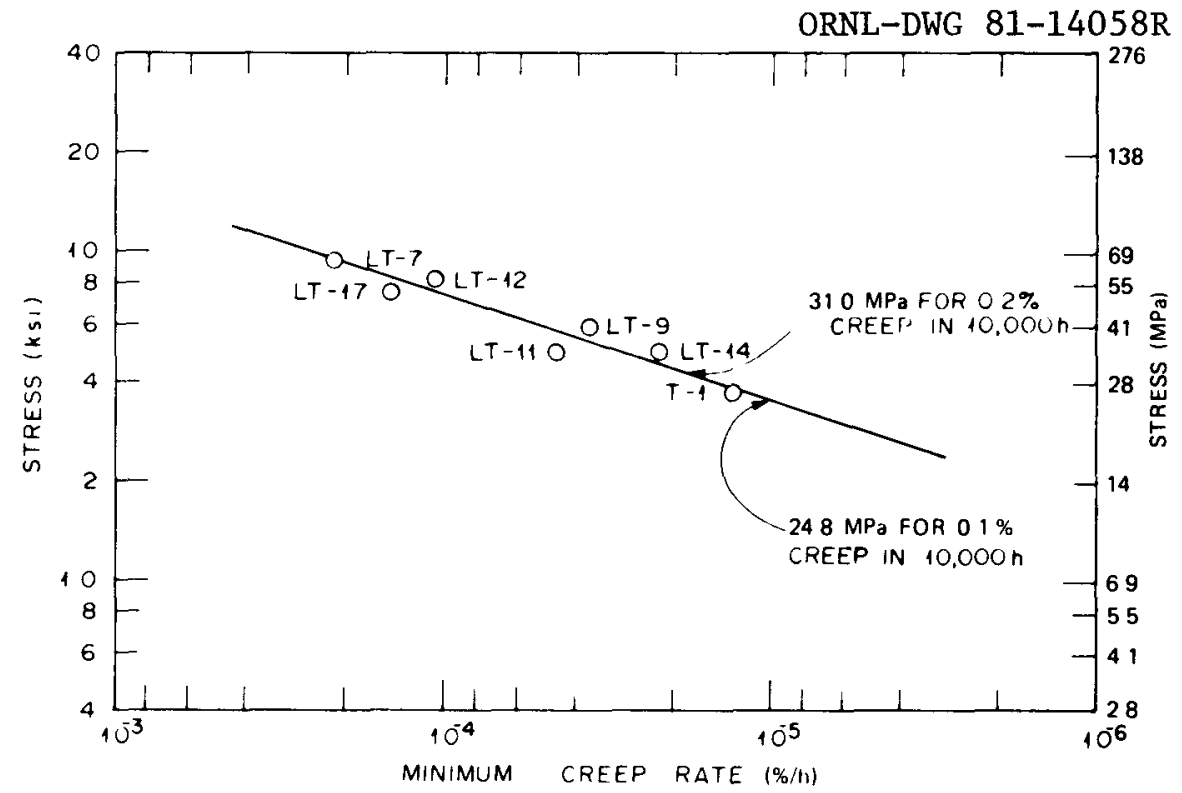

Fig. 9. Graph of 2219 T6 forging showing stress-minimum creep rate relationship at $260^{\circ} \mathrm{C}$.

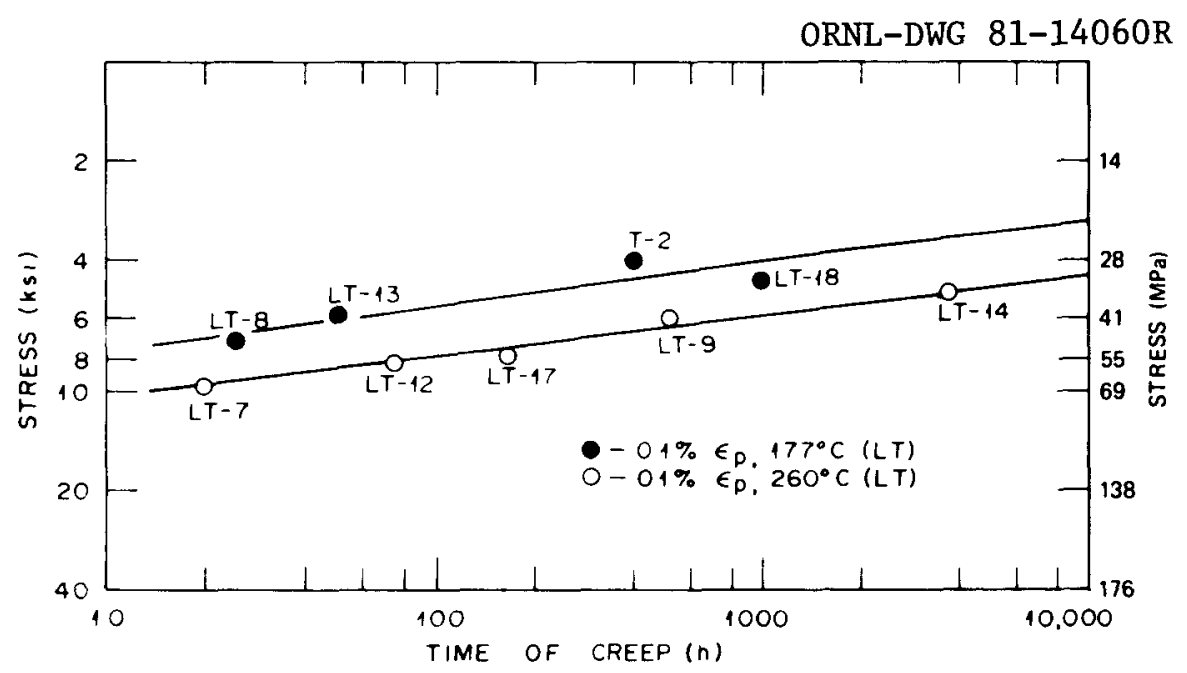

Fig. 10. Design curves of 2219 T6 forging comparing stress-time relationships for $0.1 \%$ creep at 177 and $260^{\circ} \mathrm{C}$. 


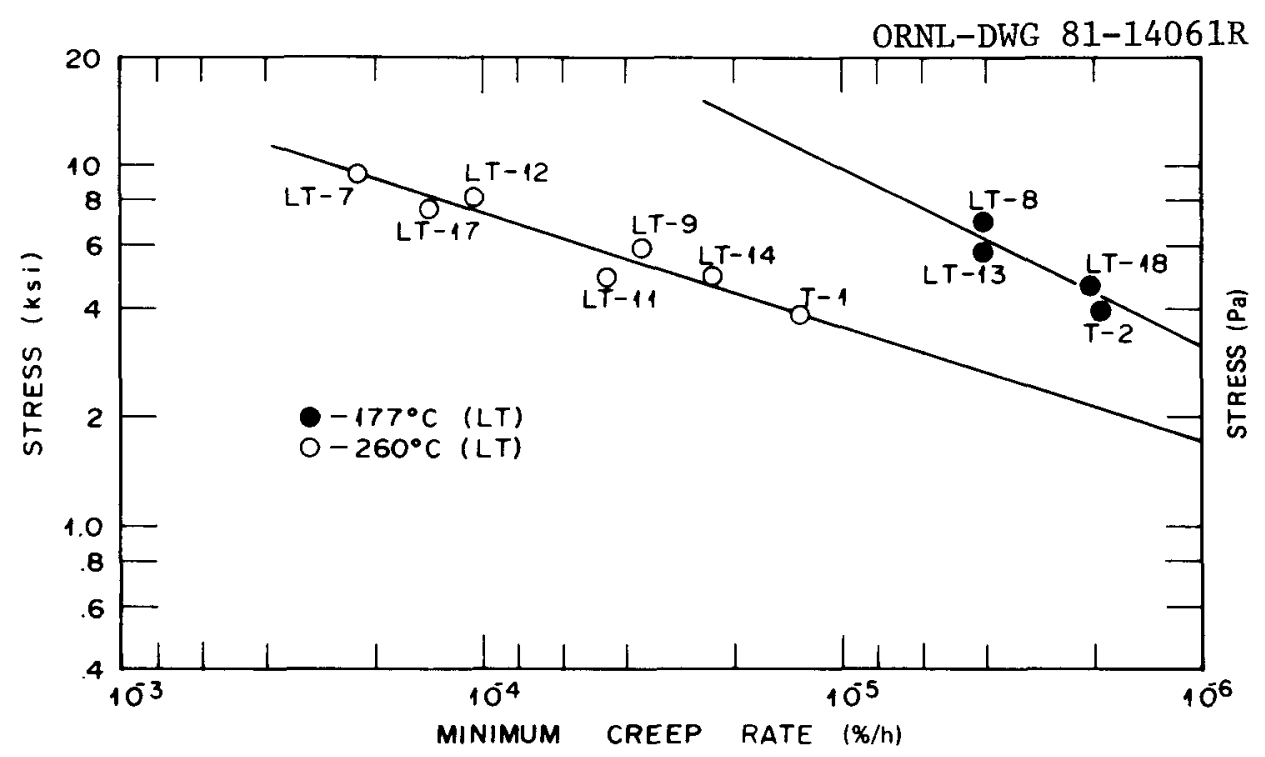

Fig. 11. Graph of 2219 T6 forging comparing stress-minimum creep rate relationships at 177 and $260^{\circ} \mathrm{C}$.

On the other hand, the relative behavior of minimum creep rate between the two test temperatures was expected; that is, the effect of decreasing the test temperatures was to decrease the minimum creep rate. This is shown in the graph in Fig. 11, which presents the stress-minimum creep rate curves at 177 and $260^{\circ} \mathrm{C}$.

At $177^{\circ} \mathrm{C}$ a projected stress of only about $20.7 \mathrm{MPa}$ was required to produce $0.1 \%$ creep in $10,000 \mathrm{~h}$, whereas at $260^{\circ} \mathrm{C}$ a stress of $28.9 \mathrm{MPa}$ was required, as pointed out earlier (Fig. 10). For $0.1 \%$ strain by secondary creep, it appears on the basis of the data $\left(\dot{\varepsilon}_{m}\right.$ mark of $10^{-5 \% / h}$ in Fig. 11) that about $62.0 \mathrm{MPa}$ would be required at $177^{\circ} \mathrm{C}$, whereas (as noted earlier) a stress of only $24.8 \mathrm{MPa}$ would be needed at $260^{\circ} \mathrm{C}$.

The preliminary tests listed in Table 2 ( $\mathrm{L}-1$ and $\mathrm{L}-2$ ) were for specimens taken in the longitudinal direction of the forging and tested for comparatively short times $(\sim 1000 \mathrm{~h})$ at the two test temperatures. A11 other specimens tested were of long-transverse orientation.

A comparison of the secondary creep rates on the longitudinal specimens at 260 and $177^{\circ} \mathrm{C}$ with creep rates established at the same stresses and over the same time for the long-transverse specimens indicated the latter to have the lower creep strength. 
At $260^{\circ} \mathrm{C}$ the long-transverse specimen crept more than 4 times faster than did the longitudinal, and at $177^{\circ} \mathrm{C}$ more than 3 times faster. This was expected. The room-temperature tensile and yield strengths of the 2219 T6 aluminum alloy as a die forging, for example, are reported to be somewhat higher in the direction parallel to the grain axis than at right angles. 8

\section{DISCUSSION}

The most pertinent information on the creep-rupture properties of the 2219 T6 aluminum forge alloy with which to compare our results was deve1oped by the Alcoa New Kinsington Laboratory in the sixties. 8 This data included time to 0.1 and $0.2 \%$ strain from room temperature to $371^{\circ} \mathrm{C}$ at $56^{\circ} \mathrm{C}$ increments but excluded the $204^{\circ} \mathrm{C}$ test temperature and did not go beyond $1000 \mathrm{~h}$. Our 0.1 and $0.2 \%$ creep design curves at $260^{\circ} \mathrm{C}$ are compared with the Alcoa data in Fig. 12.

The Alcoa data reflect considerably higher resistance to creep in the region around $1000 \mathrm{~h}$ and higher. However, the two separate sets of curves converge on one another as the time of testing diminishes, suggesting that the tensile strengths of the materials may not be greatly different.

Because the Alcoa data fail to report the orientation of test specimens in the forging, it is possible that the moderate superiority of the Alcoa data over ours may result from their test specimens having been taken from the longitudinal orientation. A second possible explanation may lie in the comparative grain sizes of the two forgings and differences in chemical homogeneity resulting from the extent of hot working.

Figure 13 shows the microstructure of the failed creep specimen LT-12 (long-transverse orientation) after testing at $260^{\circ} \mathrm{C}$. The field of view is in the gage length normal to the specimen axis. Note that the grain size is very large ( $>$ ASTM No. 1) and that considerable coring (microsegregation) from the cast billet remains in the forging. The trace amount of imperfections (arrows) is typical and is believed to be shrinkage cavities not closed by the forging operation.

Figure 14 shows the microstructure of specimen LT-12 at the failed surface (field of view parallel to specimen axis). An internal semicontinuous rupture is seen off the failed interface, and both fracture 


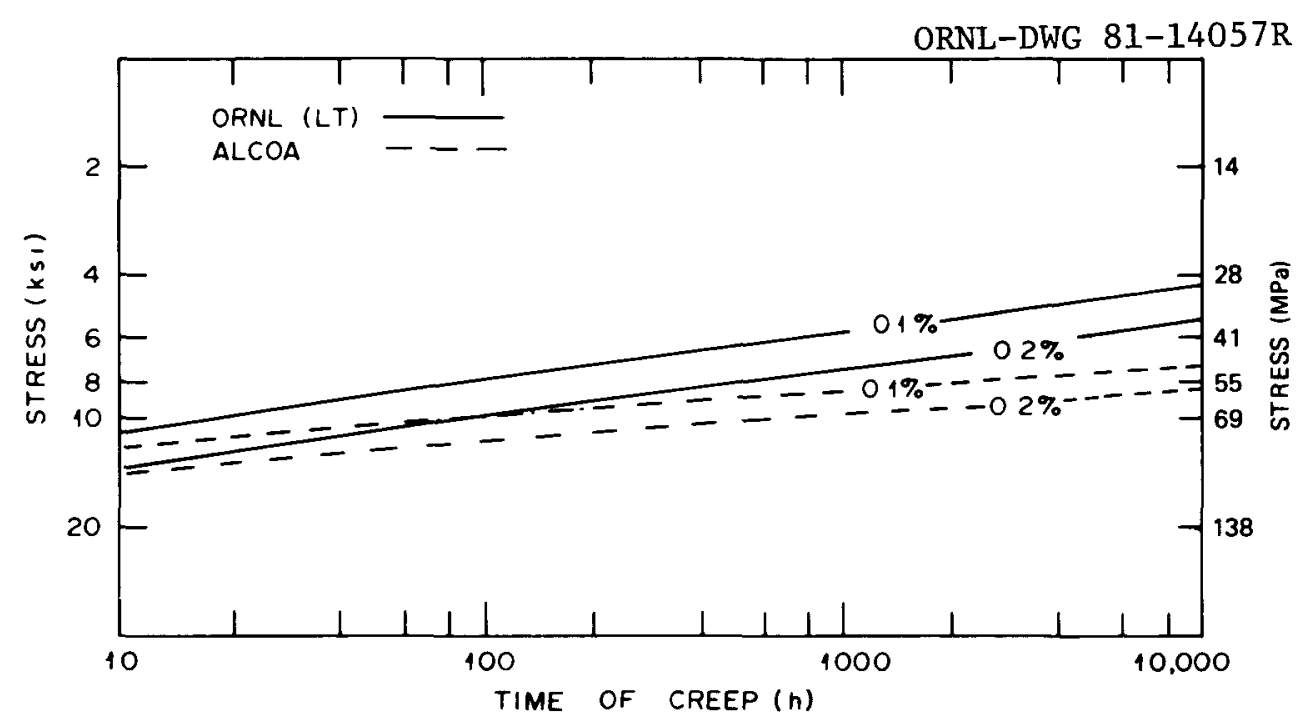

Fig. 12. Comparison of our design curves at $260^{\circ} \mathrm{C}$ (stress-time for 0.1 and $0.2 \%$ creep) of 2219 T6 forging with Alcoa data.

surfaces clearly are intergranular. Because the test temperature $\left(260^{\circ} \mathrm{C}\right)$ was approximately 0.6 of the alloy's absolute melting temperature (high in relation to equicohesive temperature), it is not surprising that the specimen failed intergranularly instead of transgranularly.

The creep bursts that we observed in proof test I $\left(270^{\circ} \mathrm{C}\right)$, test LT-9 $\left(260^{\circ} \mathrm{C}\right)$, and $\mathrm{LT}-13\left(177^{\circ} \mathrm{C}\right)$ produced small amounts of strain compared with that of other investigators where the phenomenon has surfaced.5-7 Sikka and David obtained bursts as large as $1.7 \%$ on cast ingots of type 316 stainless steel, whereas ours ranged only from $0.01 \%$ to about $0.02 \%$ in size. They generally obtained zero to three bursts per test, whereas we obtained zero to two bursts per test except for proof test I (Fig. 5), where four or possibly five bursts occurred. The strain from bursts in the latter test gave an accumulated strain of $0.07 \%$, or about $10 \%$ of the total strain. In assessing the strain from bursts in our tests, one must recognize that some of the creep tests were not run to completion.

Sikka and David 6 associated the creep burst phenomenon with cast or welded structures and attributed it to the differential concentration of creep "strengthening elements" in the interdendritic regions as compared with the dendrite arms. They suggest that the prominence of bursts is related to the coarseness and degree of segregation in the cored 
structure. Although Da Silveria and Monteiro ${ }^{7}$ report creep bursts in wrought wires of types 316 and 304 stainless steel, Sikka and David point out that the open literature has examples of researchers' reporting their material to be wrought but that the material still contained as-cast inhomogeneities. Our instance of the observed slightly cored microstructure in the current 2219 T6 forged material appears to support this contention.

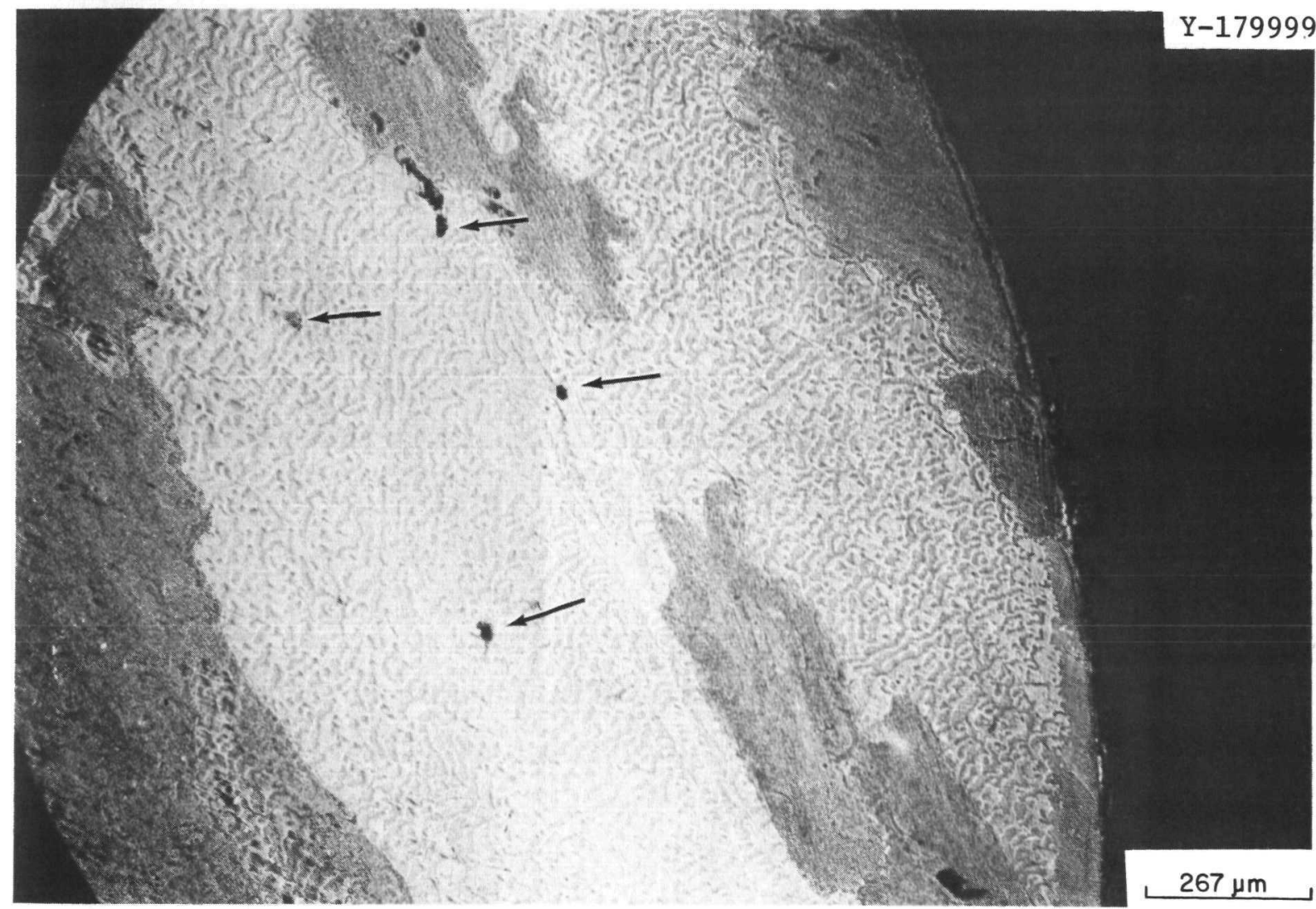

Fig. 13. Microstructure of failed creep specimen LT-12 removed from fracture surface.

The most unexpected material behavior in this study is illustrated by Fig. 10 and is associated with the fact that the $0.1 \%$ creep design curve at $177^{\circ} \mathrm{C}$ falls into a stress regime substantially lower than that for the $260^{\circ} \mathrm{C}$ design curve. This behavior means that, for the time frame of $100 \mathrm{~h}$, for example, a lower stress is required to produce $0.1 \%$ creep 


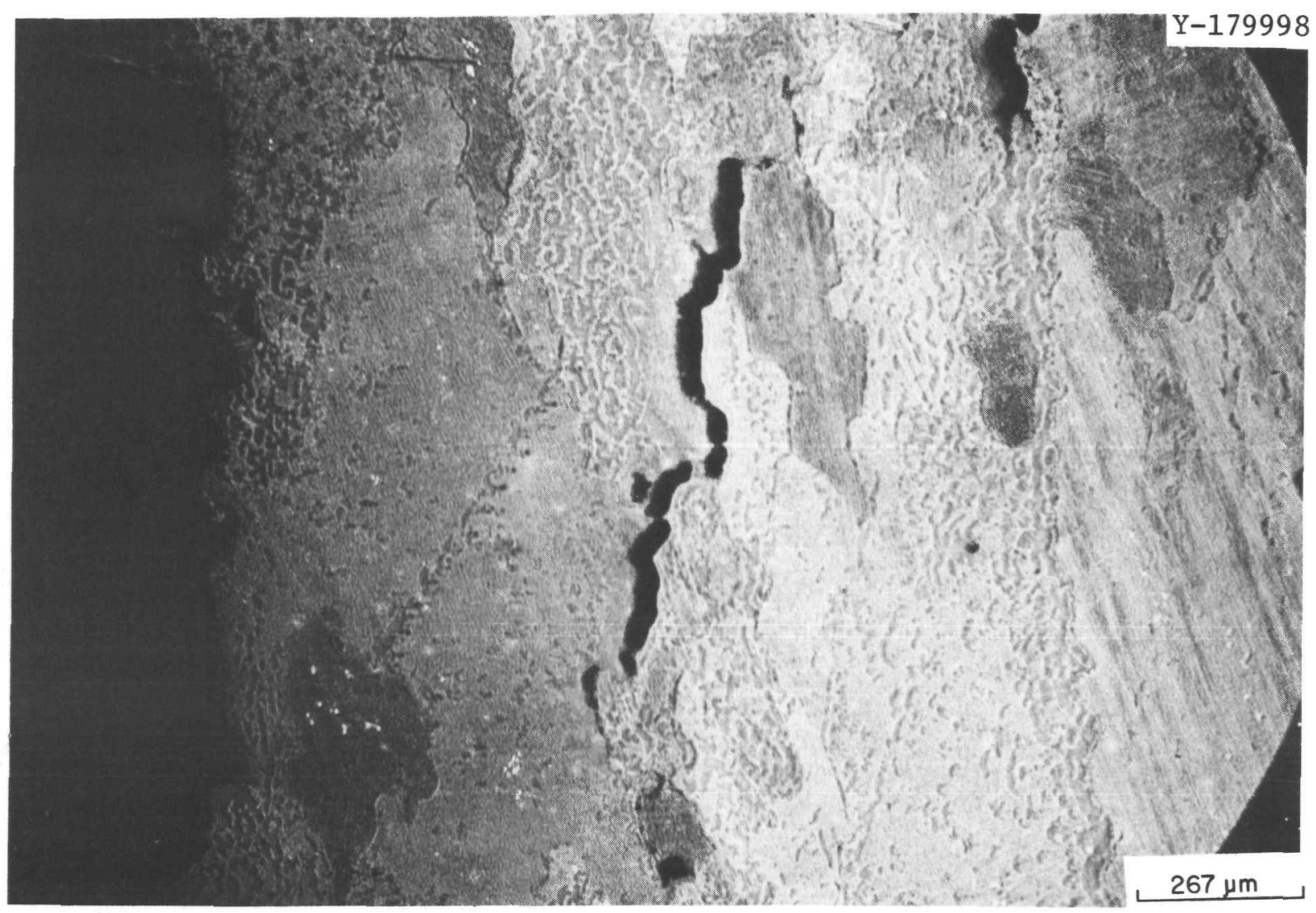
surface.

Fig. 14. Microstructure of failed creep specimen LT-12 at fracture strain at $177^{\circ} \mathrm{C}$ than at $260^{\circ} \mathrm{C}$. Ordinarily, a higher stress would be required. A second manifestation of this behavior is that, for the same loading stress, a shorter time is required to produce $0.1 \%$ creep at $177^{\circ} \mathrm{C}$ than at $260^{\circ} \mathrm{C}$. Again, the converse of this was expected; that is, a longer time should be required to produce $0.1 \%$ creep at $177^{\circ} \mathrm{C}$ than at $260^{\circ} \mathrm{C}$. The foregoing judgments, of course, are based on the premise that creep is caused by metal flow and that the activation energy is lower for such flow at the higher temperature.

It is possible that the foregoing behavior results from an unstable microstructural state that contributes to creep at the $177^{\circ} \mathrm{C}$ test temperature but that does not do so at $260^{\circ} \mathrm{C}$ because of its having been annealed out during the loadup period incident to testing.

The foregoing explanation may be shown to be plausible by examining creep behavior deduced from stress-rupture tests performed on 2219 T6 forged material at the Alcoa New Kinsington Laboratory. 8 
Figure 15 presents creep-rupture data with stress and temperature as the coordinates. Curves are shown for $0.1,0.2$, and $0.5 \%$ creep and rupture. Note that a consistent pattern is portrayed at all test temperatures except in that temperature region having thermal recovery of the material as a factor $\left(\sim 191^{\circ} \mathrm{C}\right)$. Observe also that the recovery affects only the early stage of creep and does not appear to influence later stages (secondary and tertiary creep). Finally, microstructural instability responsible for the anomaly does not seem to operate at the lower temperatures; that is, the unstable structure must not anneal out at $100^{\circ} \mathrm{C}$ and lower.

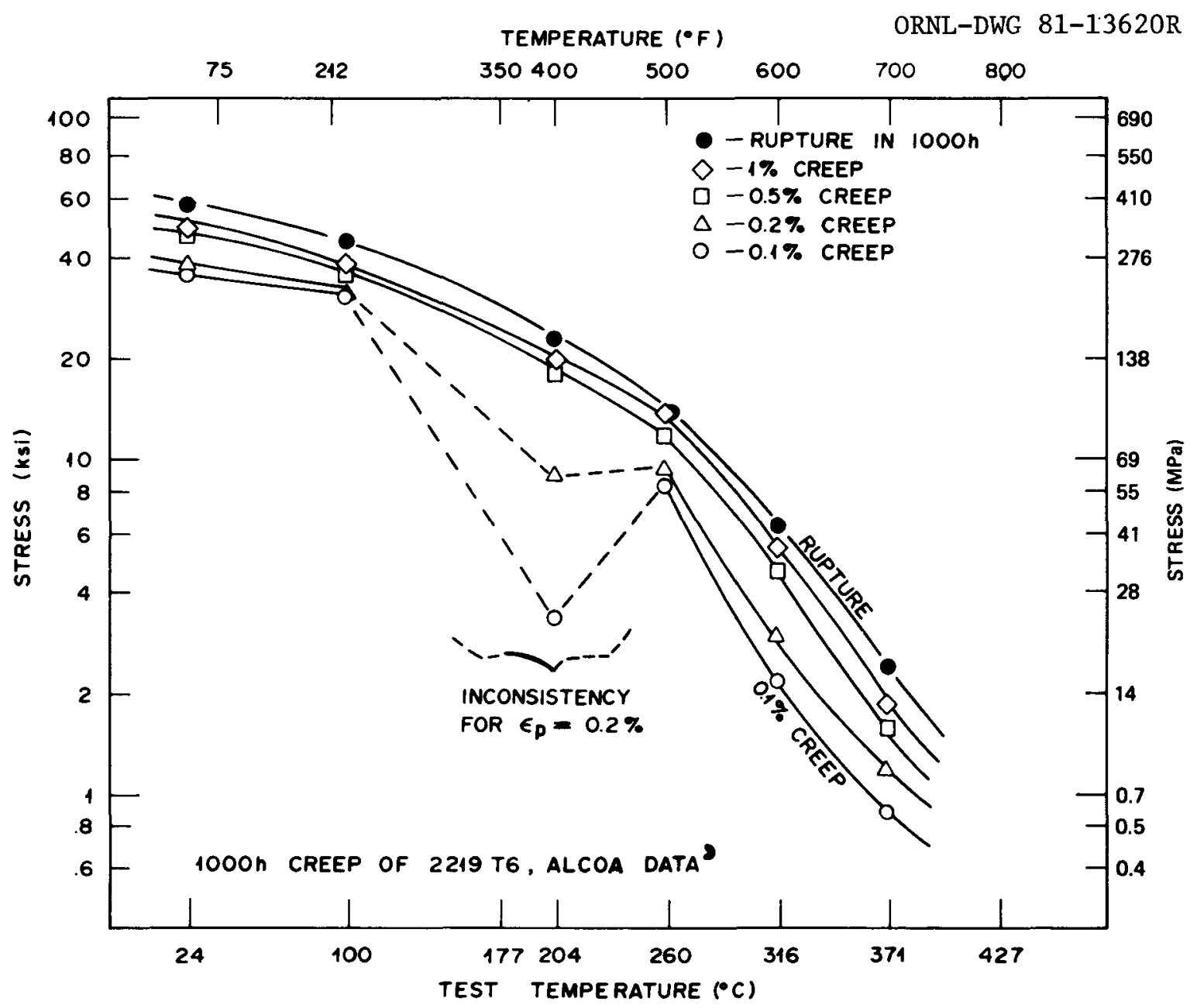

Fig. 15. Stress-temperature relationship for increasing amounts of creep of 2219 T6 forging. 
RECOMMENDATIONS

Two recommendations are made to afford a better understanding of the projected service performance of the 2219 T6 aluminum shell component of the GPHS-RTG. First, it is advisable after the earlier tests are completed to subject the two tests now under way to the conditions of space flight (proof test I) in order to assess the creep that occurs with prestorage and ground storage (proof tests IIA and B). This is needed to examine the implications of the life fraction rule as applied to the service performance of this component.

One aspect of this rule is that exposure effects at different conditions are cumulative. For example, if one-third of the material's service life (or time to initiation of tertiary creep) is used up at $177^{\circ} \mathrm{C}$, only two-thirds of its life should remain for service at $270^{\circ} \mathrm{C}$. The 1 ife fraction rule generally works better when the earlier service is at the lower temperature rather than the higher temperature, 3 as is the case for our ground storage and space flight.

Things to be established by the consecutive proof tests on the same sample include (1) the extent to which the primary creep in the space exposure (test I) is diminished as a result of the prior history on the ground (test II); (2) the extent, if any, to which secondary creep rate in space is affected by prior exposures; and (3) the extent to which the useful life in space is diminished (time of second-stage creep) by prior exposures.

The second recommendation is that the creep specimens exposed at 177 and $260^{\circ} \mathrm{C}$ be examined by electron transmission metallography to explain why the creep behavior during early-stage creep appears to be distinctly different at $177^{\circ} \mathrm{C}$ from that at the higher temperature. It is possible that the excessive primary creep activity at $177^{\circ} \mathrm{C}$ is caused by a polygonization of prevailing substructures or movement of dislocation entanglements at this temperature. 


\section{CONCLUSIONS}

Investigation of the creep properties of the 2219 T6 aluminum alloy forging to be used for the outer shell component of the GPHS-RTG led to the following conclusions:

1. Duplicate proof tests to assess the magnitude of creep during prelaunch testing and storage (600 and $10,000 \mathrm{~h}$, respectively) on the ground gave results in excellent agreement. Although primary creep was considerable $(0.11$ and $0.12 \%)$, this strain can be largely eliminated by tightening the shell supports after testing. The rate of second-stage creep was extremely low, averaging $3.5 \times 10^{-6 \% / h}$ and amounting to a strain of only $0.035 \%$ during ground service.

2. The proof test simulating conditions in space $(10,000 \mathrm{~h})$ gave about the same primary creep $(0.11 \%)$. However, the major portion of this strain is not likely to occur because of the prior creep history on the ground. The minimum creep rate of the second-stage creep was $4.5 \times$ $10^{-5} \% / \mathrm{h}$ or $0.45 \%$ in $10,000 \mathrm{~h}$. Mild "creep bursts" occurred during the latter half of the test, which increased the second-stage creep to about $0.66 \%$.

3. We concluded that the major element of concern about the relaxation of stress in the shell by creep centers on the magnitude of secondstage creep during the service in space at $270^{\circ} \mathrm{C}, 34.4 \mathrm{MPa}$. Although our assessments of creep for ground and space conditions were obtained by separate simultaneous tests (to save time), the life-fraction rule states that the creep life during later exposure is diminished in direct relationship to the fraction of life used up in early exposure. Therefore, a single continuing test that incorporates the separate service conditions in tandem is needed to assess validly the strain and/or life during service.

\section{ACKNOWLEDGMENTS}

The author gratefully acknowledges George Ambrose of the General Electric Company for counsel and help in devising the program test matrix and Ed Boling for performing the creep tests. Appreciation is expressed to R. L. Heestand and K. M. Booker for reviewing the report, to Irene Brogden for editing, and A. J. Carter for final typing. 


\section{REFERENCES}

1. Marshal Holt and K. 0. Bogardus, "The Hot Aluminum Alloys," Prod. Eng. (N.Y.) 36(17): 88-96 (1965).

2. George Ambrose, General Electric Co., King of Prussia, Pa., personal communication to J. P. Hammond, June 25, 1981.

3. P. N. Randa11, "Cumulative Damage in Creep-Rupture Tests of a Carbon Steel," Trans. ASME 240: 239-42 (1962).

4. American Soctety for Testing and Materials, "Standard Methods of Tension Testing of Metallic Materials," E 8-69, pp. 194-213; "Recommended Practice for Elevated Temperaure Tests of Metallic Materials," E 21-70, pp. 265-74 in 1971 Annual Book of ASTM Standards, Part 31, Philadelphia, 1971.

5. R. L. Klueh and J. K. King, Mechanical Properties of ERNiCr-3 Weld Metal Deposited by Gas Tungsten-Are Process with Hot Wire Filler Additions, ORNL-5491, March 1979.

6. V. K. Sikka and S. A. David, "Discontinuous Creep Deformation in a Type 316 Stainless Steel Casting," Metall. Trans. 12A: 883-92 (1981).

7. T. L. Da Silveria and S. N. Monteiro, "Jumps in the Creep Curve of Austenitic Stainless Steels," Metall. Trans. 10A: 1795-96 (1979).

8. L W. Mayer, Alcoa Aluminum Alloy 2219, Aluminum Company of America, Application Engineering Division, New Kinsington, Pa., rev. June 1967. 
25

APPENDIX

Computer Graphs of Creep Tests 
u'r

BLANK 
Table Al. Computer graphs of creep tests

\begin{tabular}{|c|c|c|c|c|}
\hline Test & Specimen & $\begin{array}{l}\text { Test } \\
\text { time } \\
(\mathrm{h})\end{array}$ & $\begin{array}{c}\text { Strain } \\
\text { scale }{ }^{a} \\
(\% / 2.54 \mathrm{~cm})\end{array}$ & Page \\
\hline 21925 & LT-11 & 9276 & 0.200 & 28 \\
\hline 21820 & LT-6 & 8467 & 0.050 & 29 \\
\hline 21820 & $\mathrm{LT}-6$ & 9833 & 0.050 & 30 \\
\hline 22270 & LT-16 & 4433 & 0.025 & 31 \\
\hline 21838 & LT-7 & 979 & 0.100 & 32 \\
\hline 21839 & LT-12 & 2600 & 0.100 & 33 \\
\hline 21867 & LT -17 & 4065 & 0.100 & 34 \\
\hline 21867 & LT-17 & 1145 & 0.050 & 35 \\
\hline 21941 & LT-9 & 4712 & 0.100 & 36 \\
\hline 21941 & LT -9 & 8455 & 0.200 & 37 \\
\hline 22032 & LT-14 & 4799 & 0.020 & 38 \\
\hline 22102 & $\mathrm{~T}-1$ & 5652 & 0.050 & 39 \\
\hline 21940 & LT-8 & 7220 & 0.100 & 40 \\
\hline 21940 & $\mathrm{LT}-8$ & 8586 & 0.050 & 41 \\
\hline 21968 & LT-13 & 6261 & 0.100 & 42 \\
\hline 21968 & LT-13 & 7615 & 0.050 & 43 \\
\hline 22070 & LT-18 & 4372 & 0.100 & 44 \\
\hline 22250 & $\mathrm{~T}-2$ & 4410 & 0.050 & 45 \\
\hline 21754 & $L-1$ & 1026 & 0.050 & 46 \\
\hline 21770 & $\mathrm{~L}-2$ & 1145 & 0.100 & 47 \\
\hline
\end{tabular}

$a_{\text {Scale reduced }} 2$ to 1 in reproduction. 


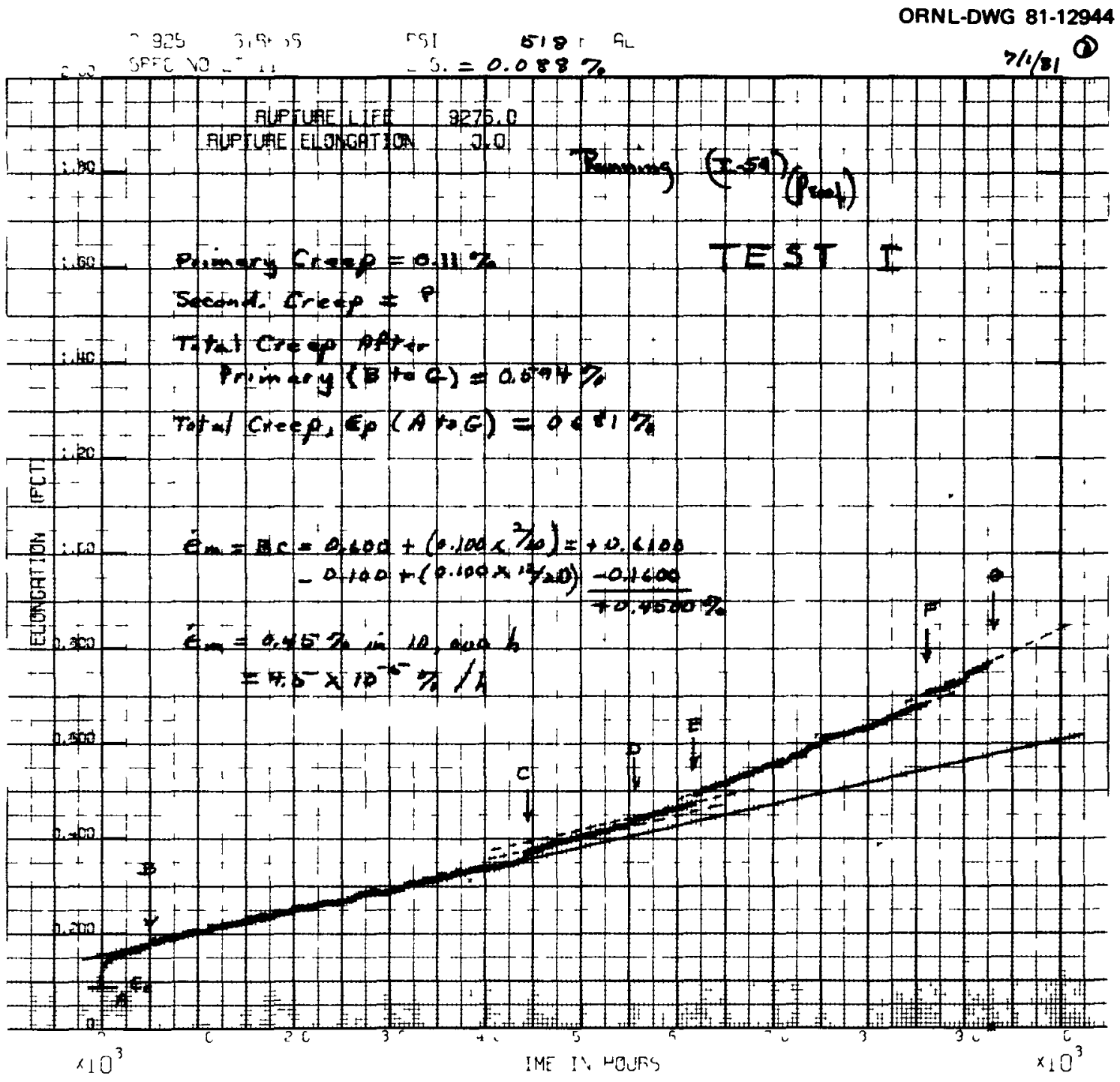




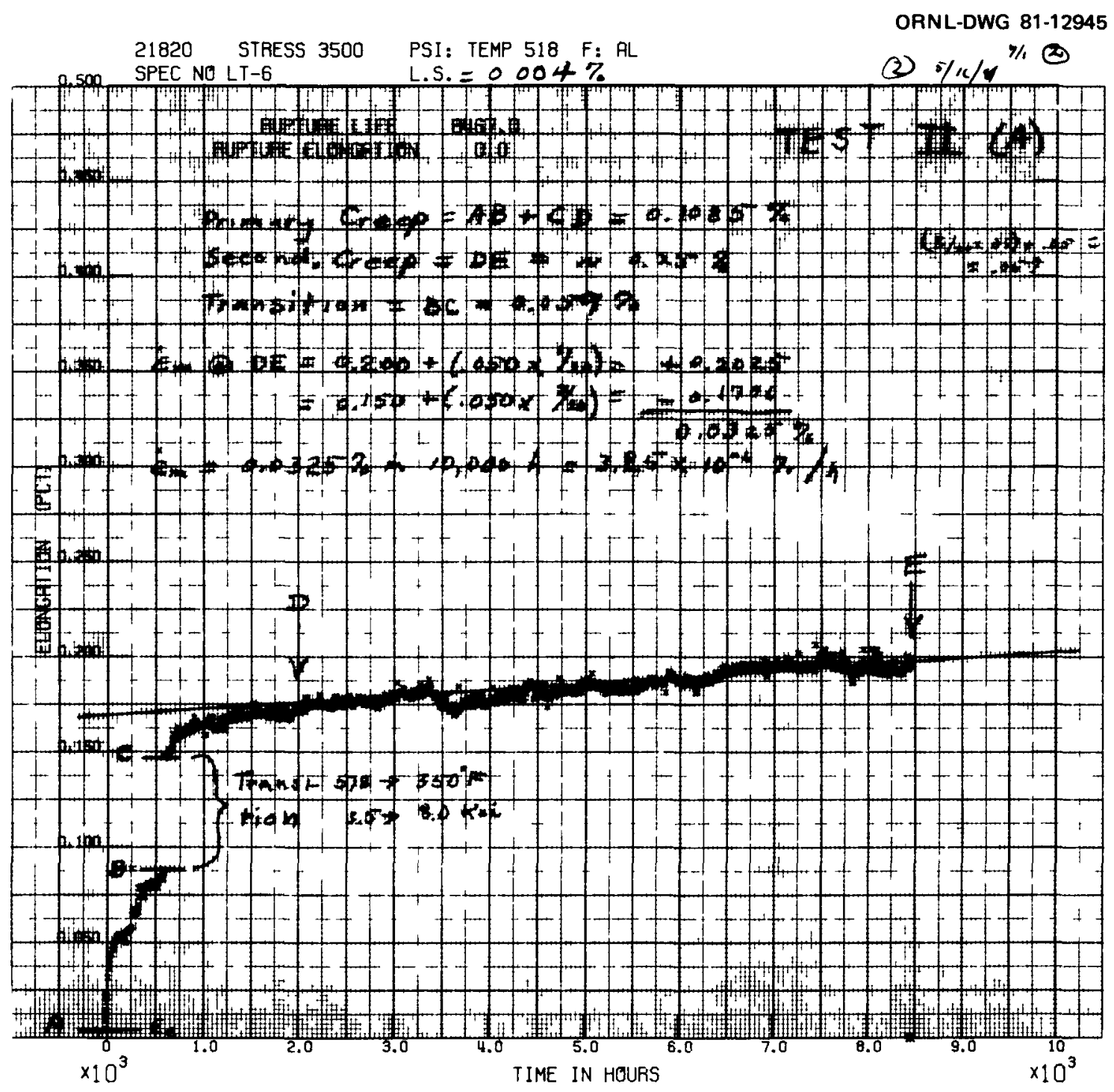




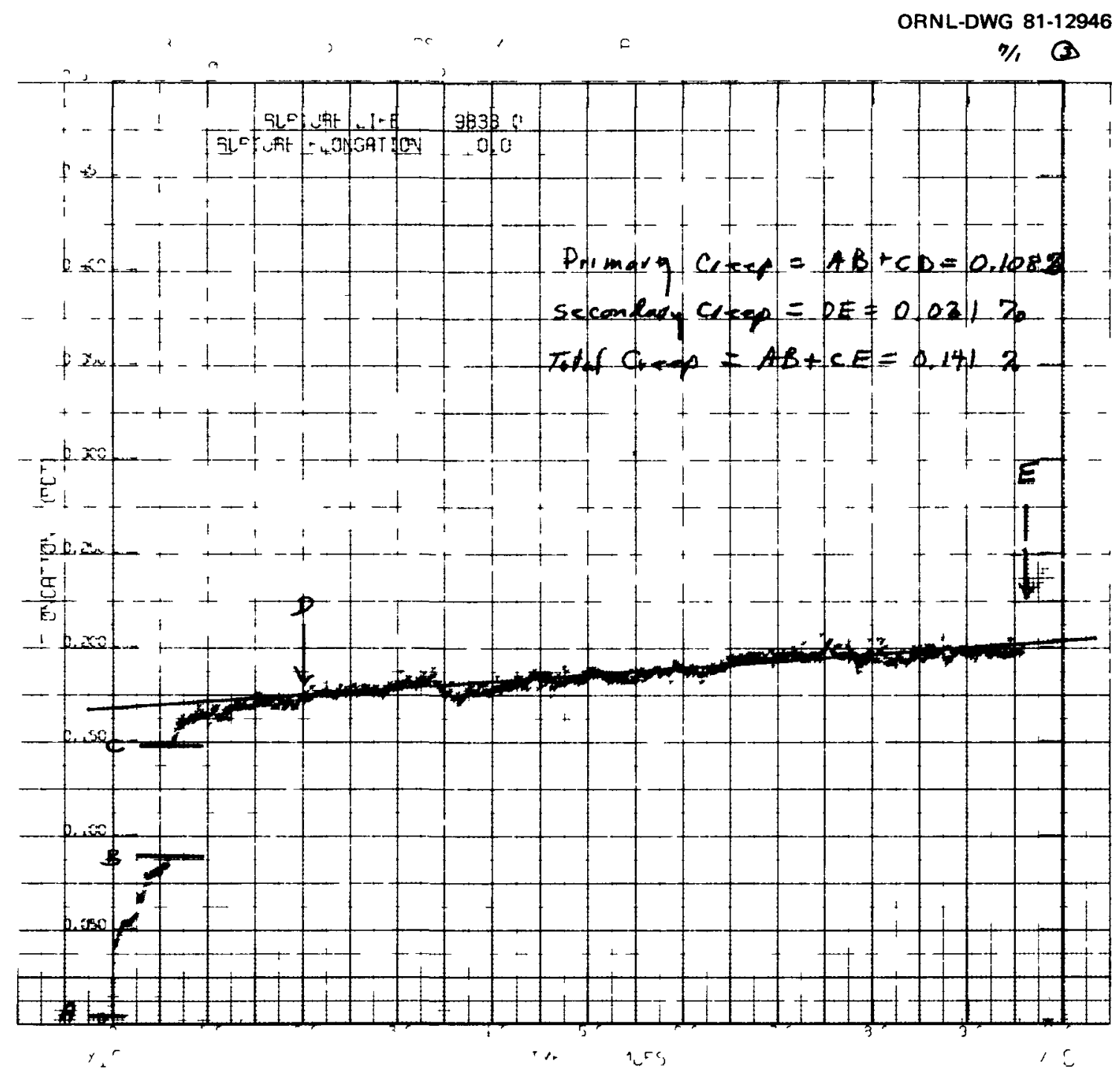




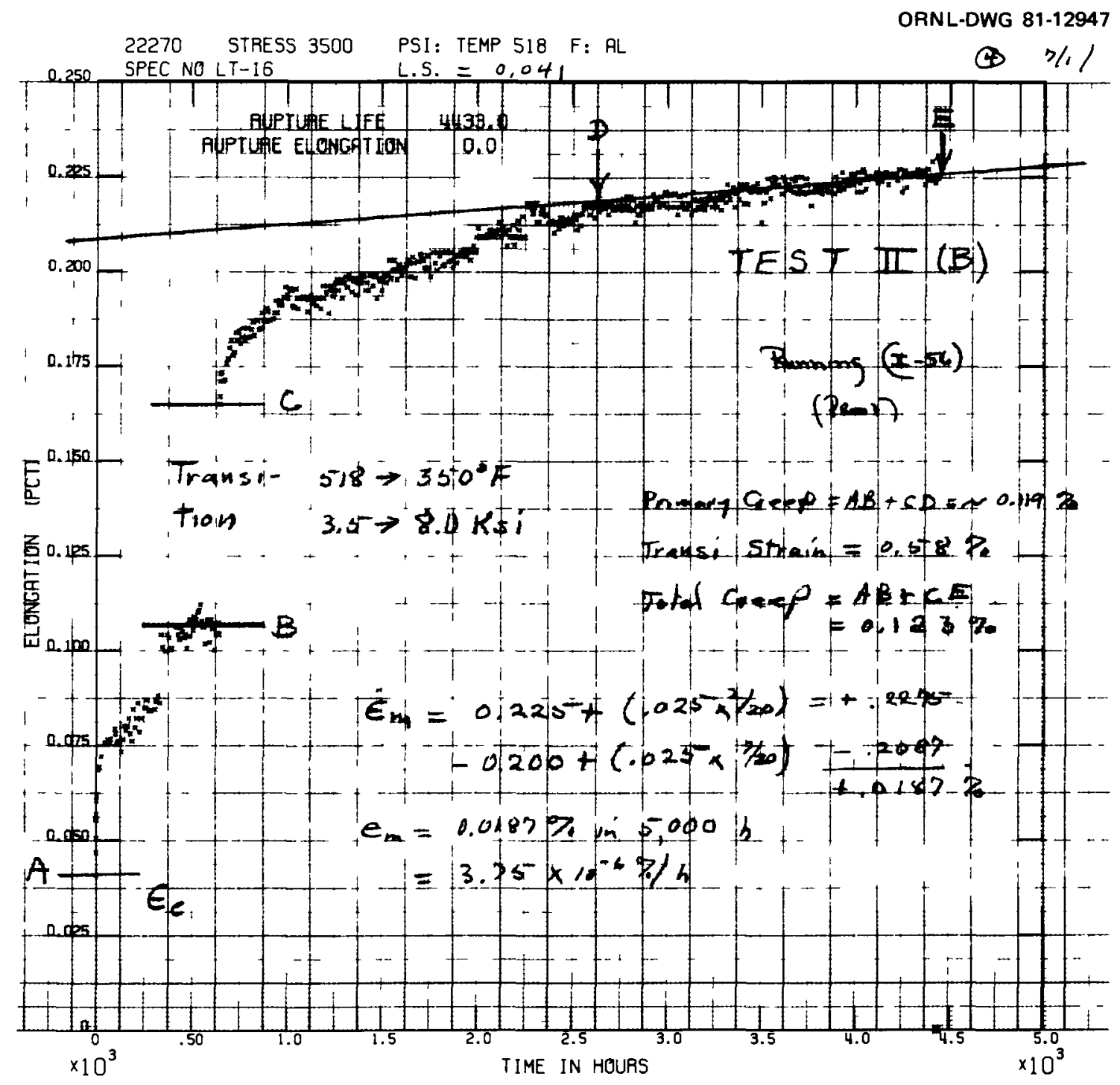




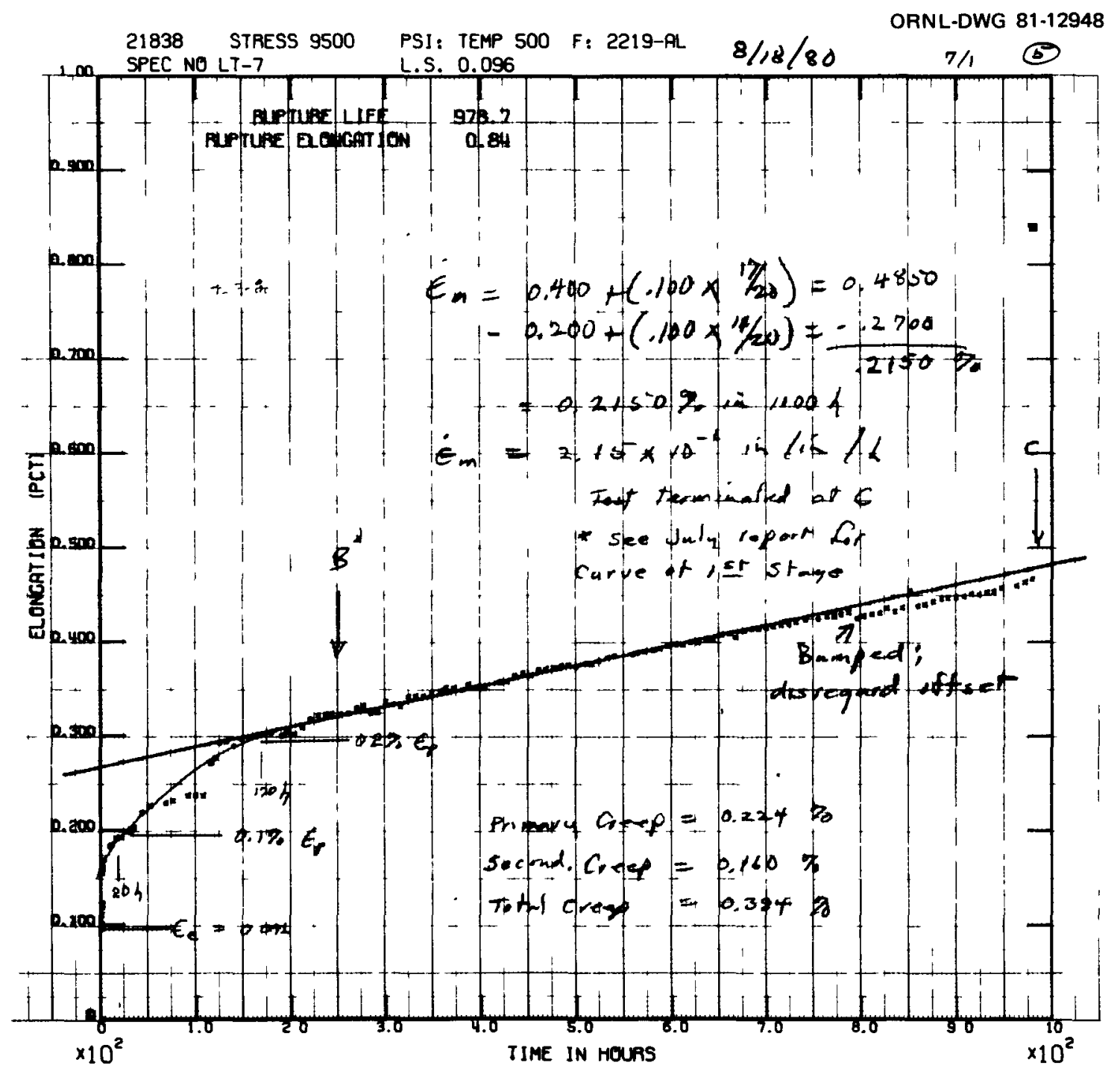




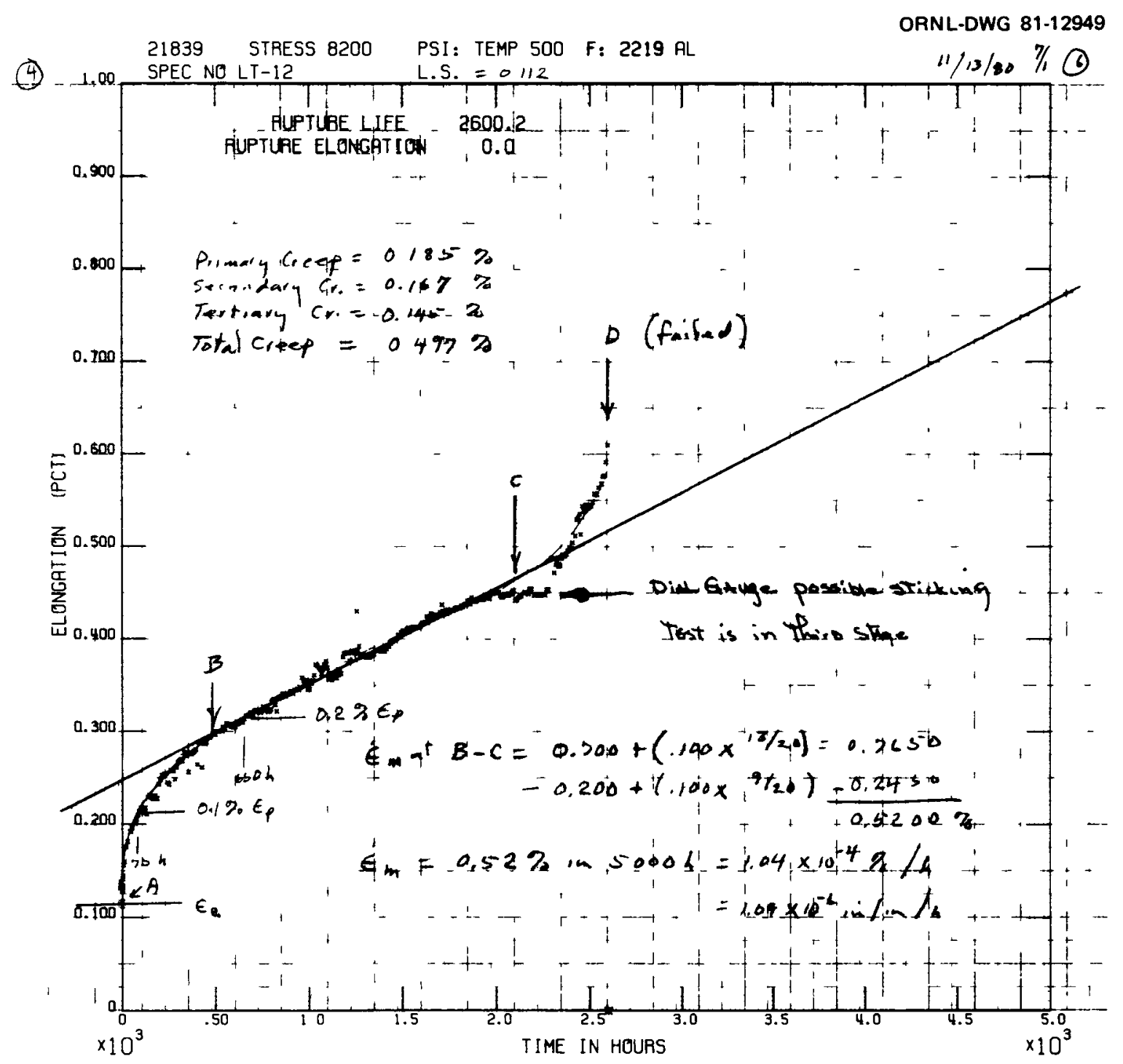




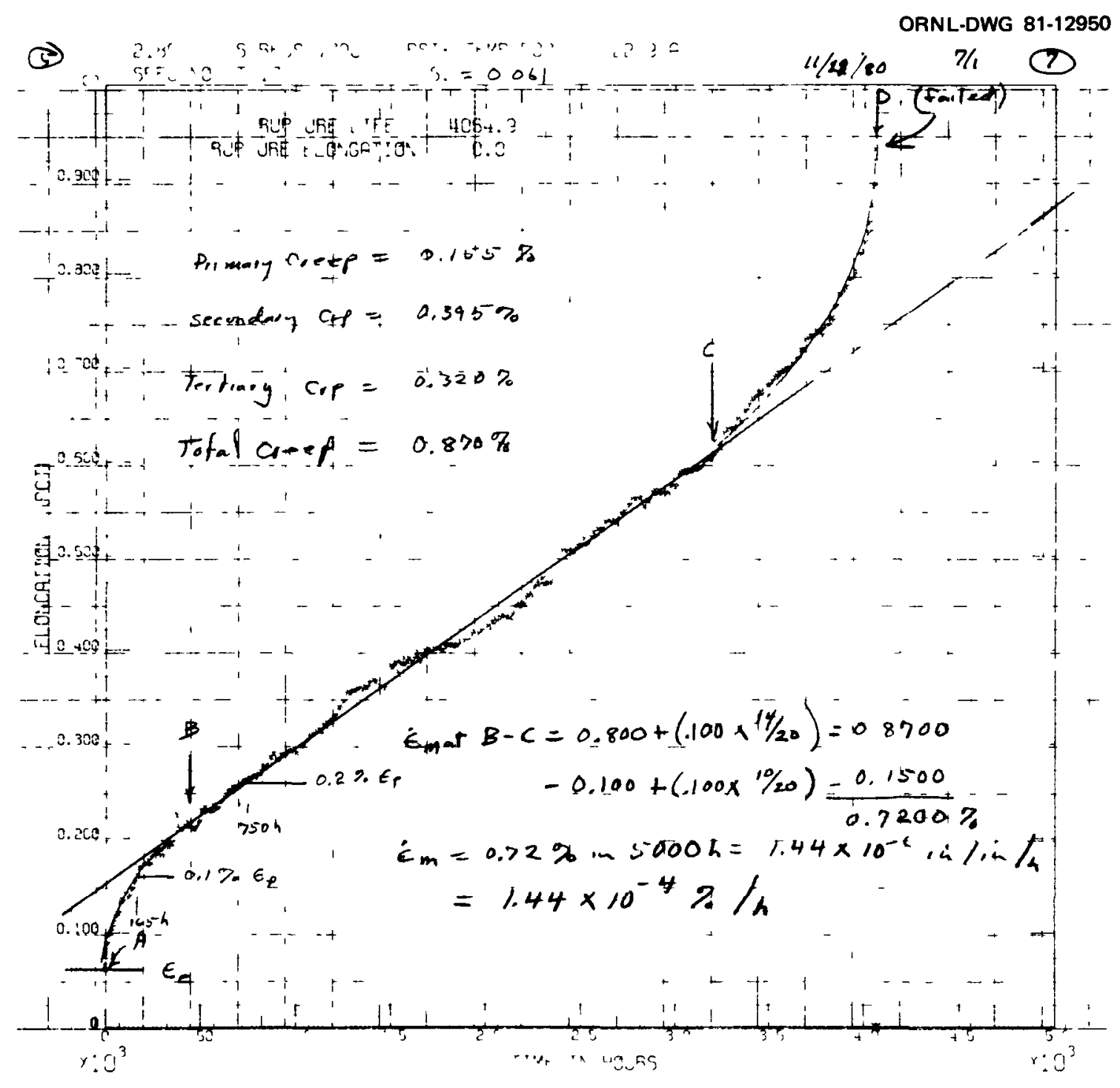




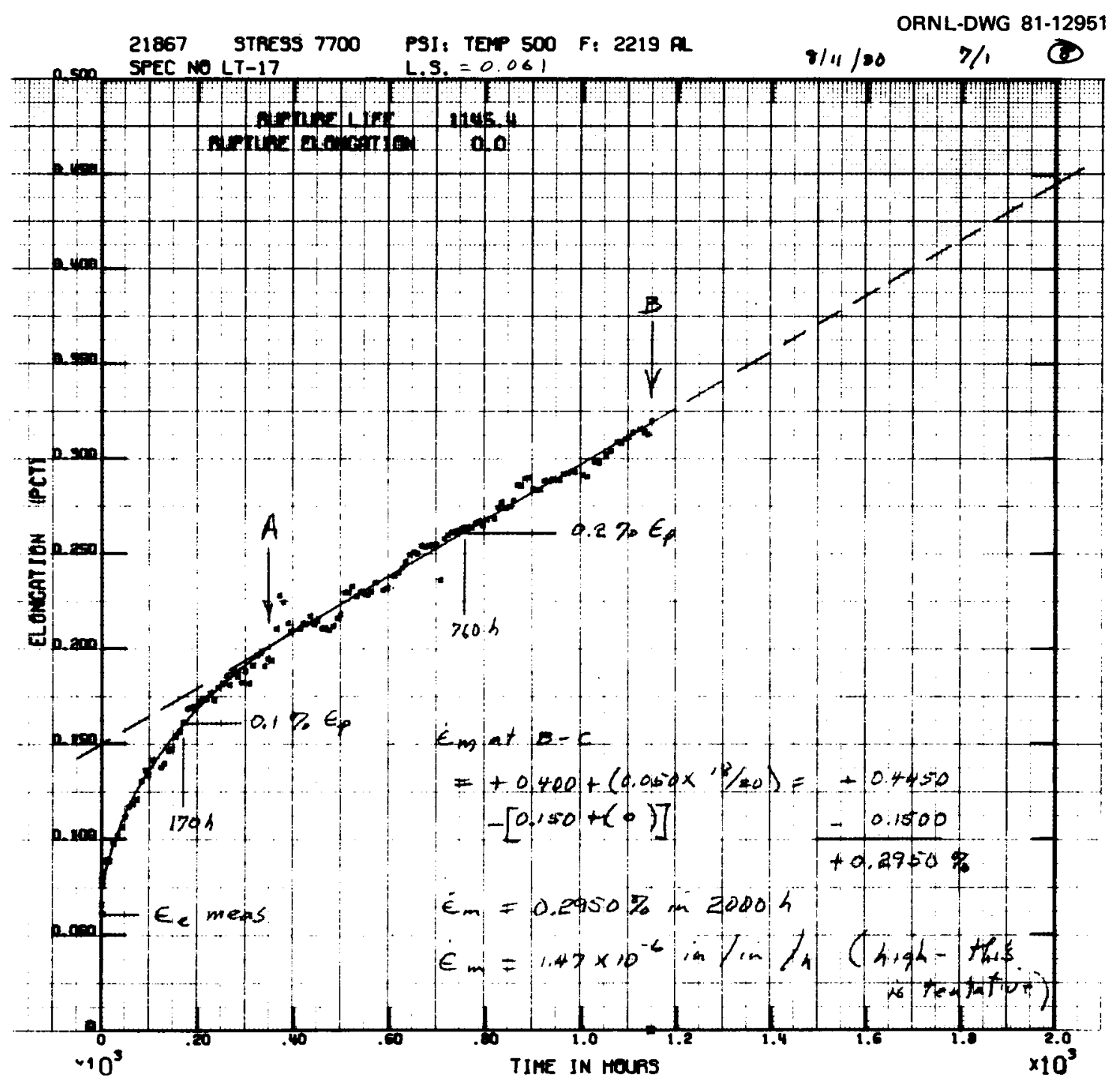




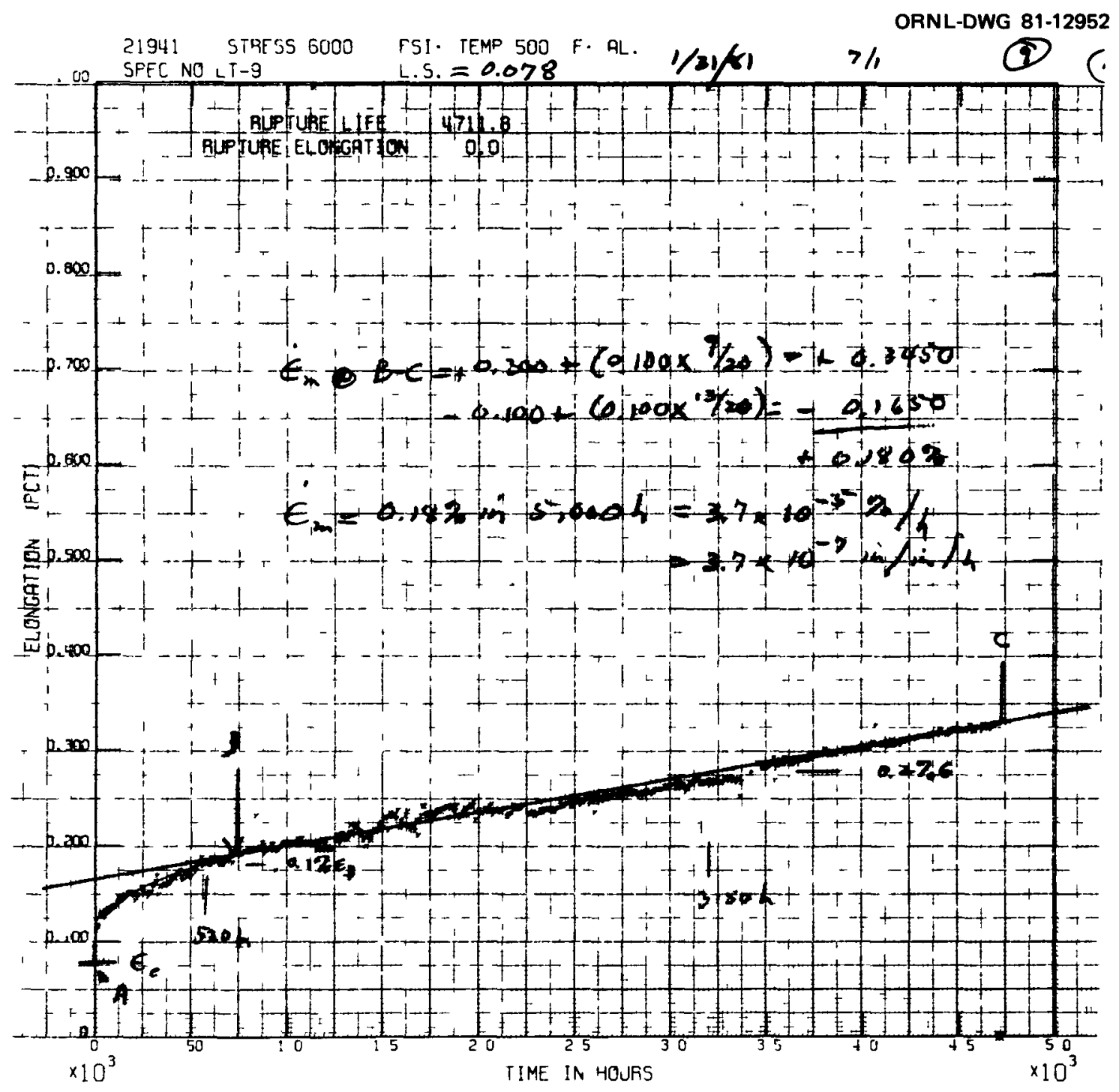


21941 5.75 SS 6000 PSI. TEMF $500 \bar{F} \cdot \bar{F}$.

ORNL-DWG 81-12953

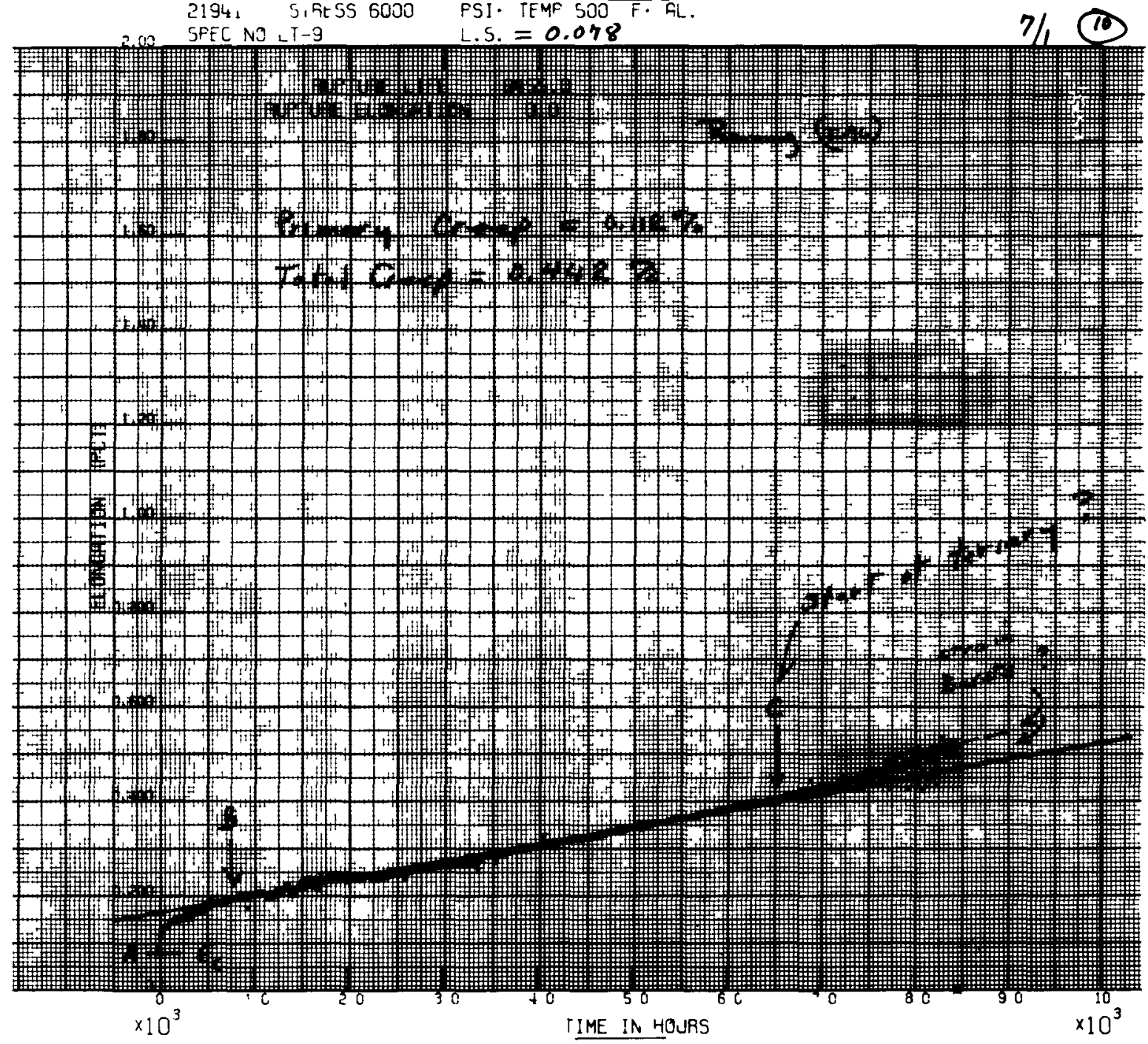




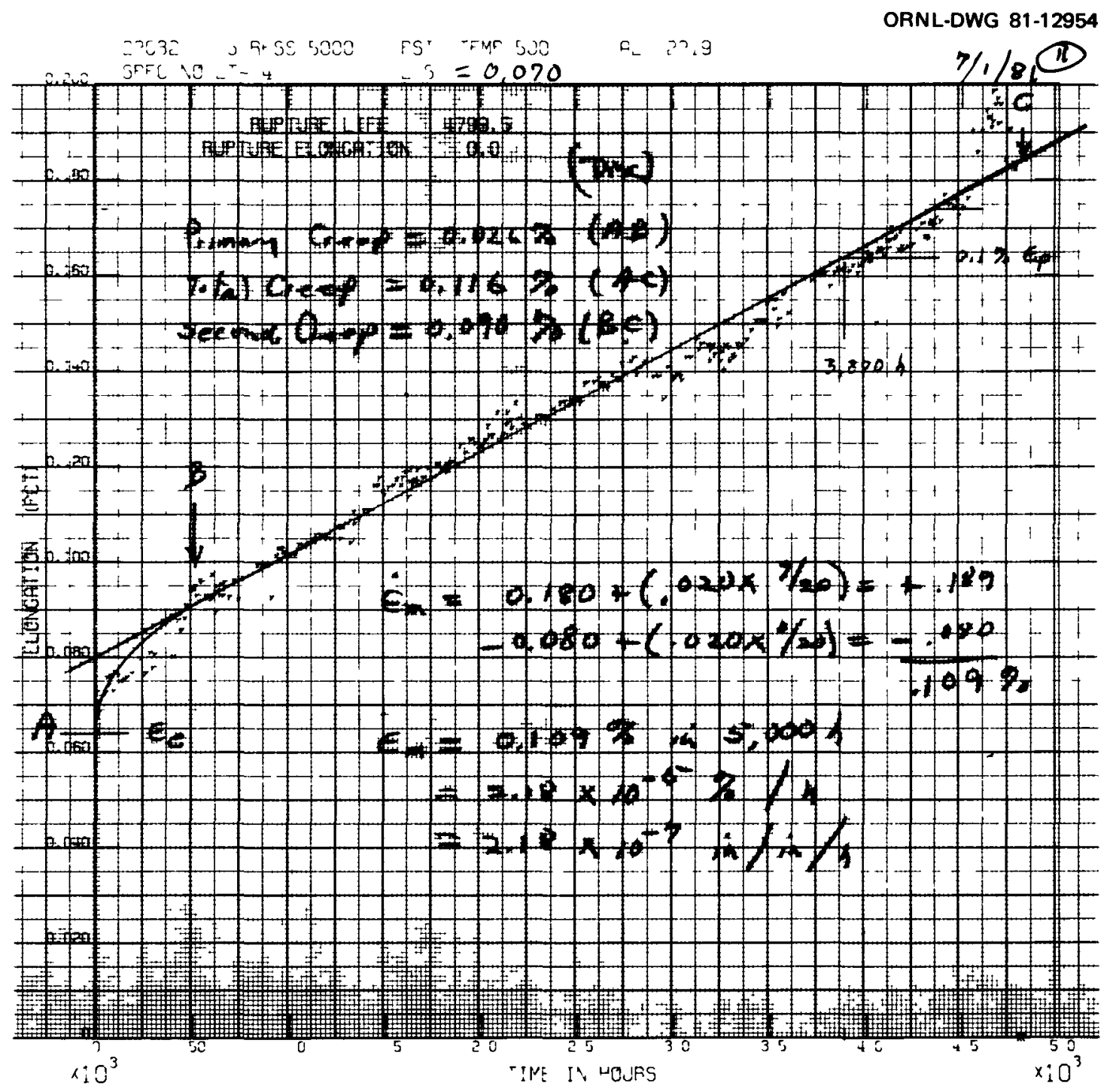




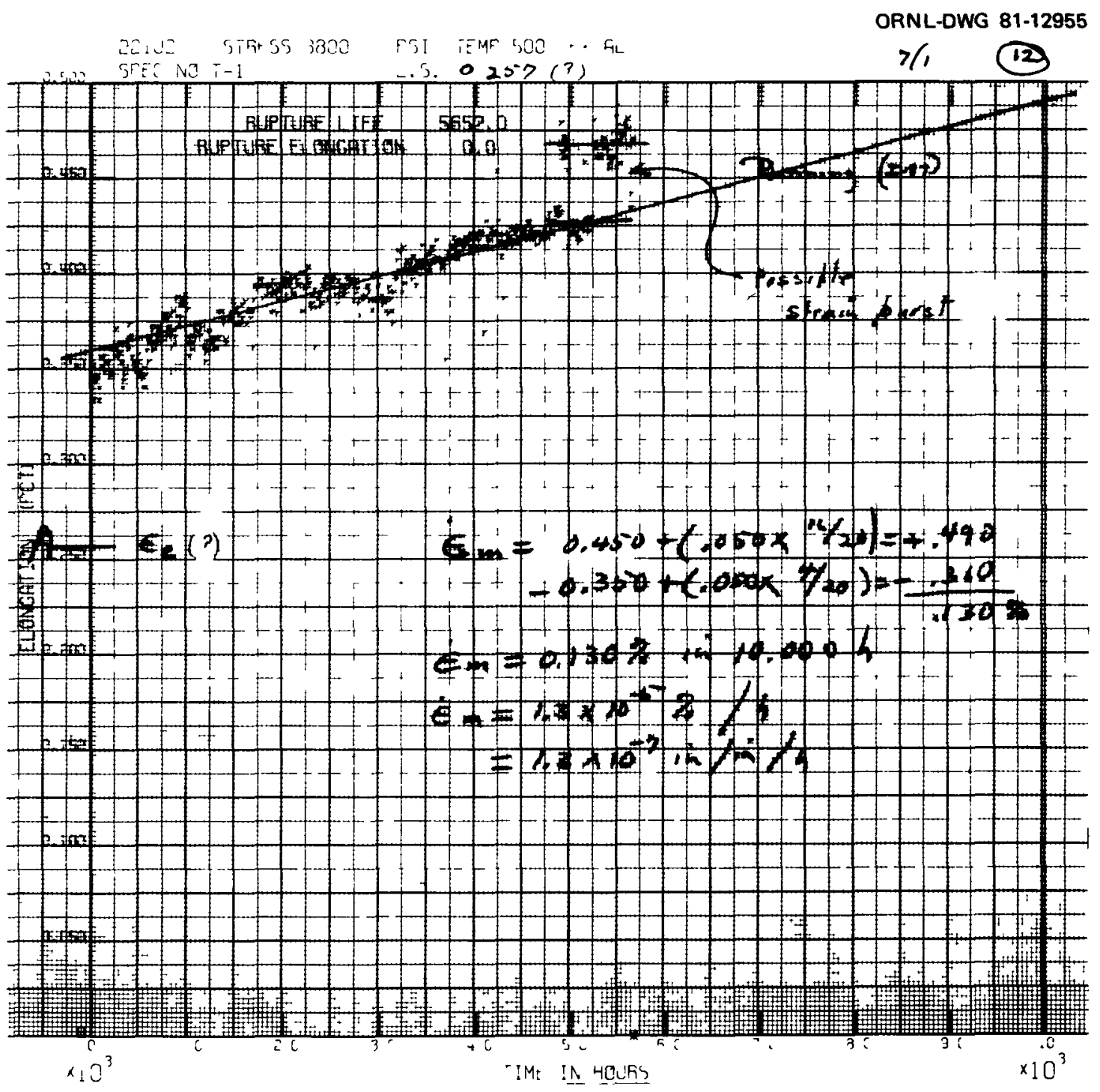




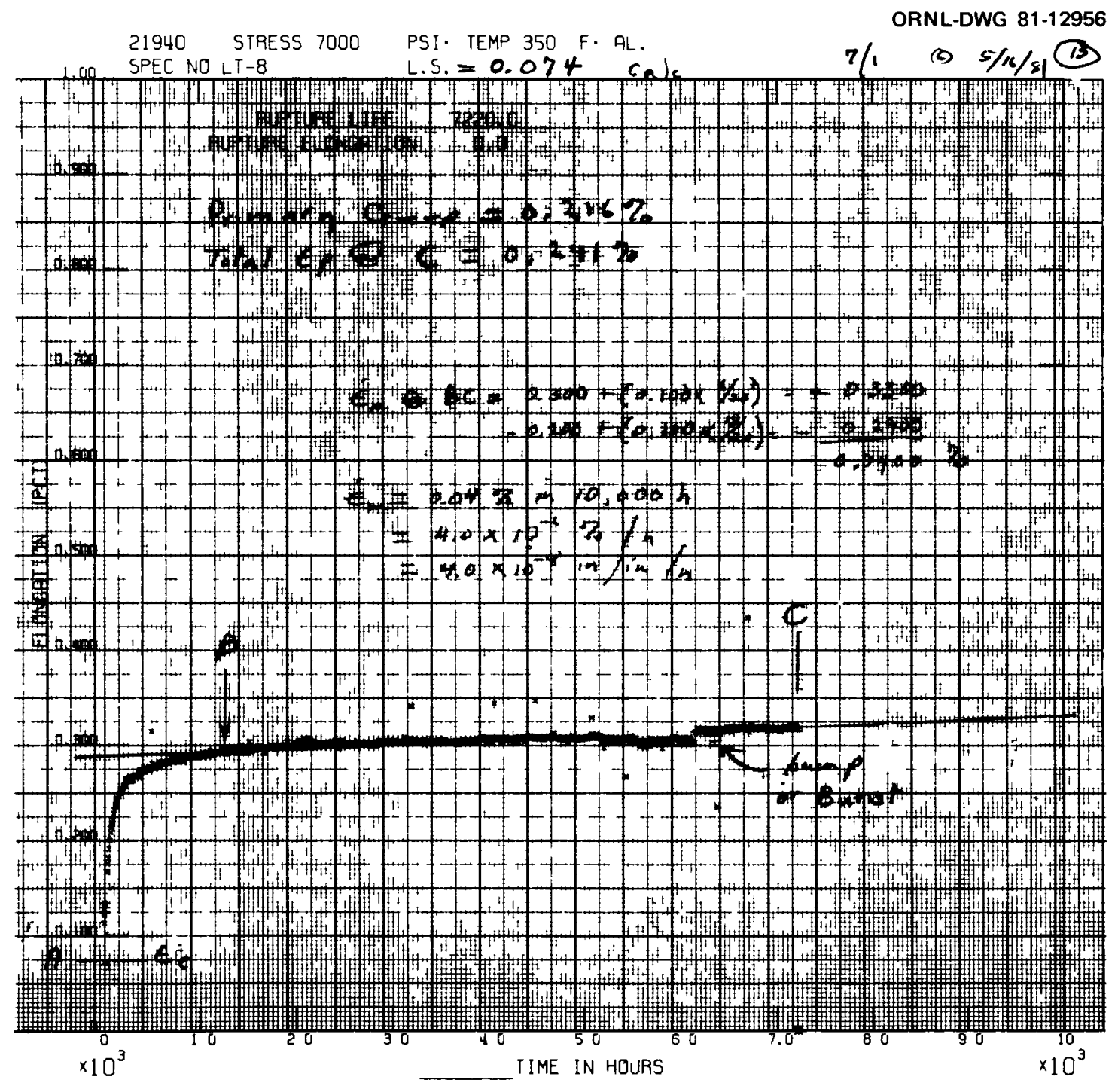




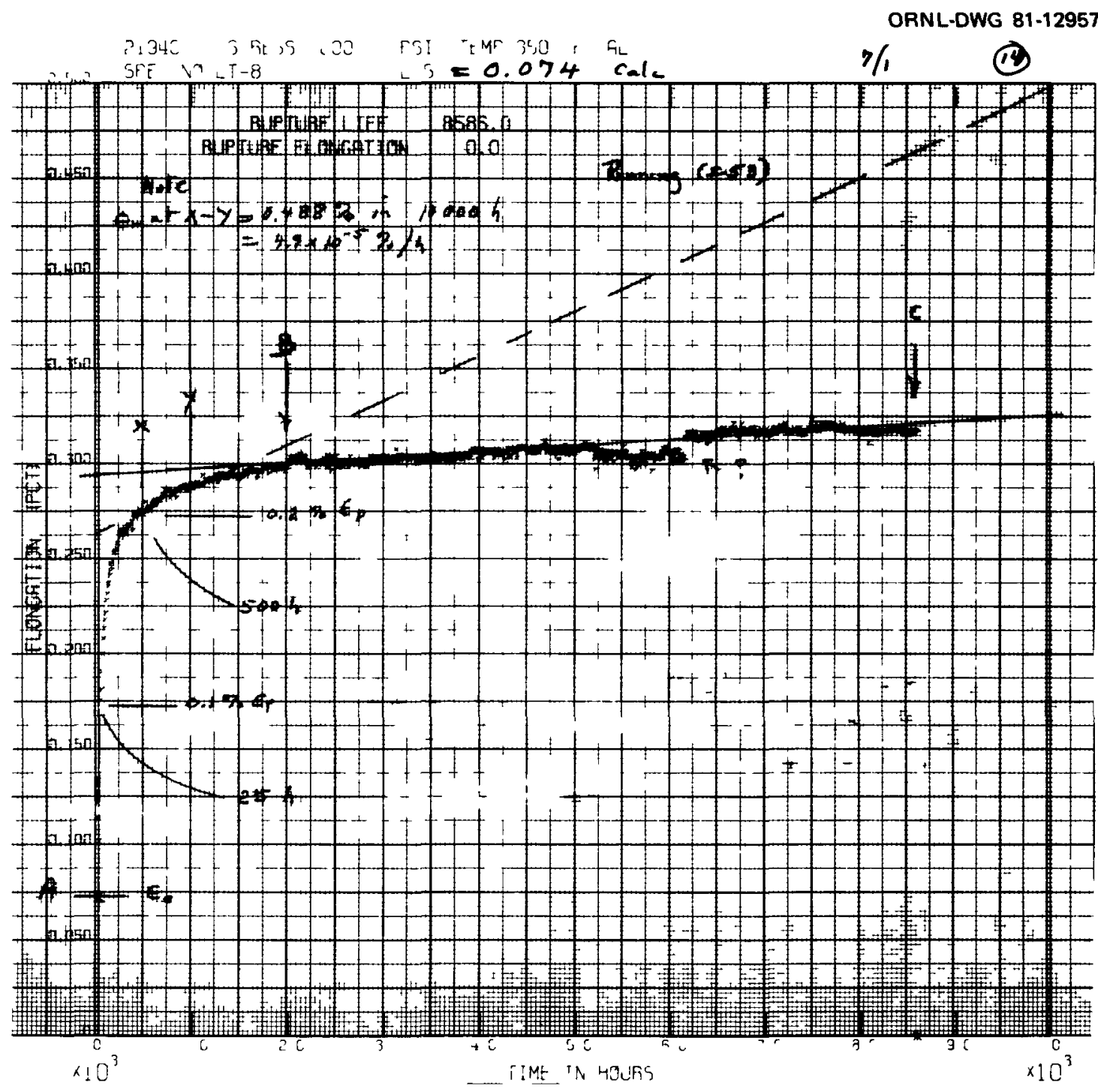




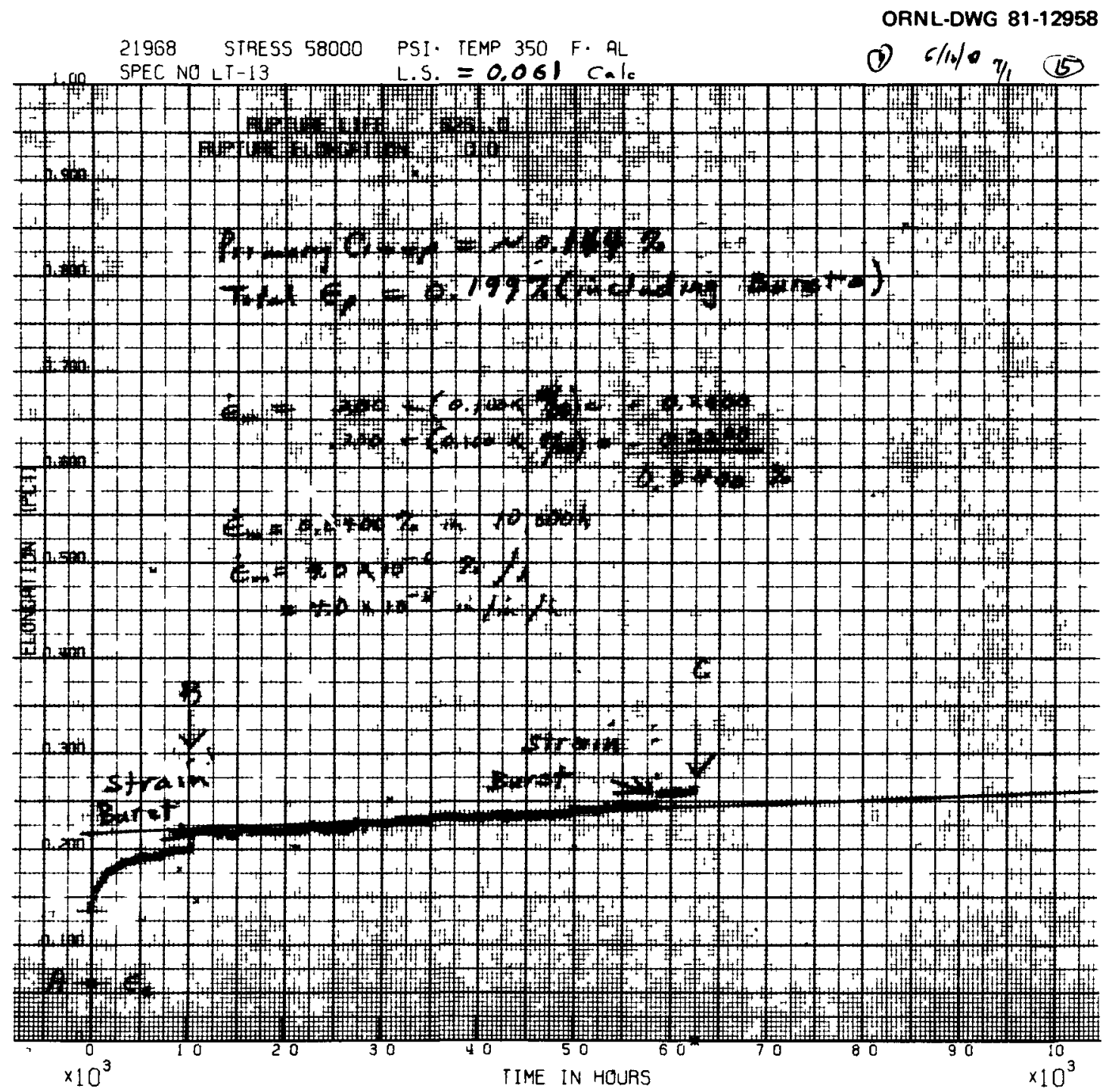


ORNL-DWG 81-12959

21968 SIFESS 58000 FSI. TEMP $350 F \mathrm{FL}$

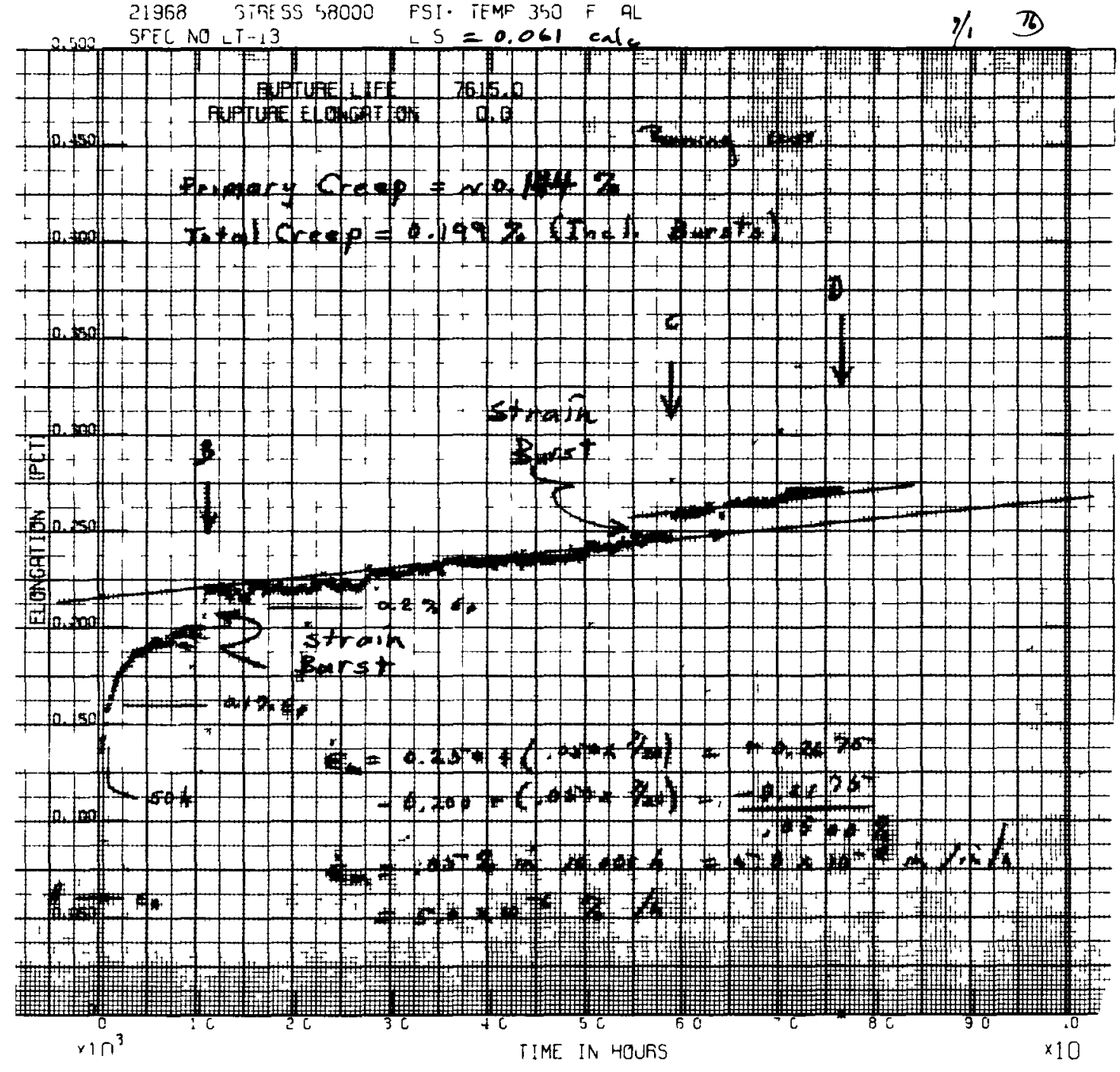


ORNL-DWG 81-12960

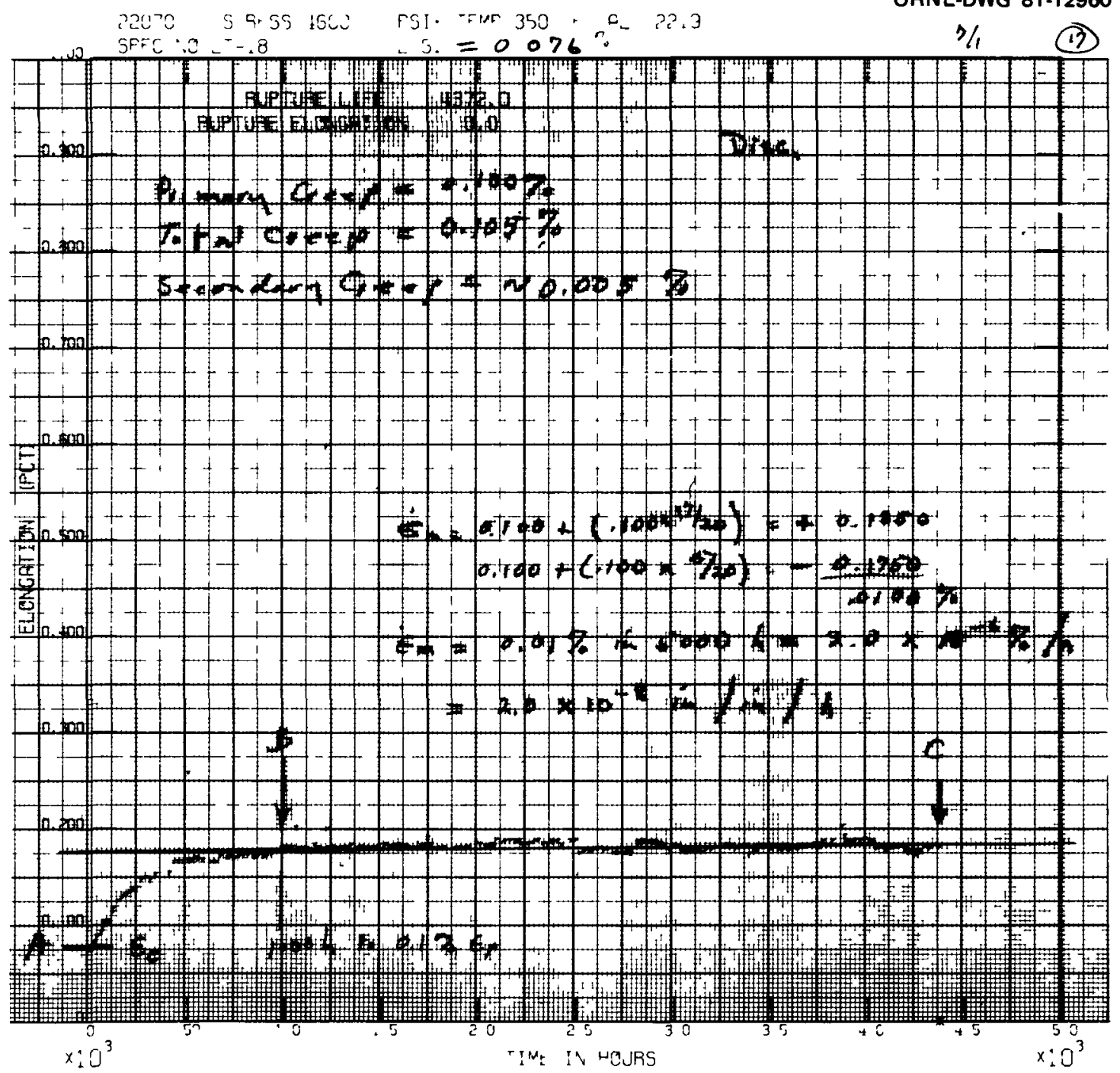


22250 STRESS 4000 PSI: TEMP $350 \mathrm{~F}$ : AL

ORNL-DWG 81-12961

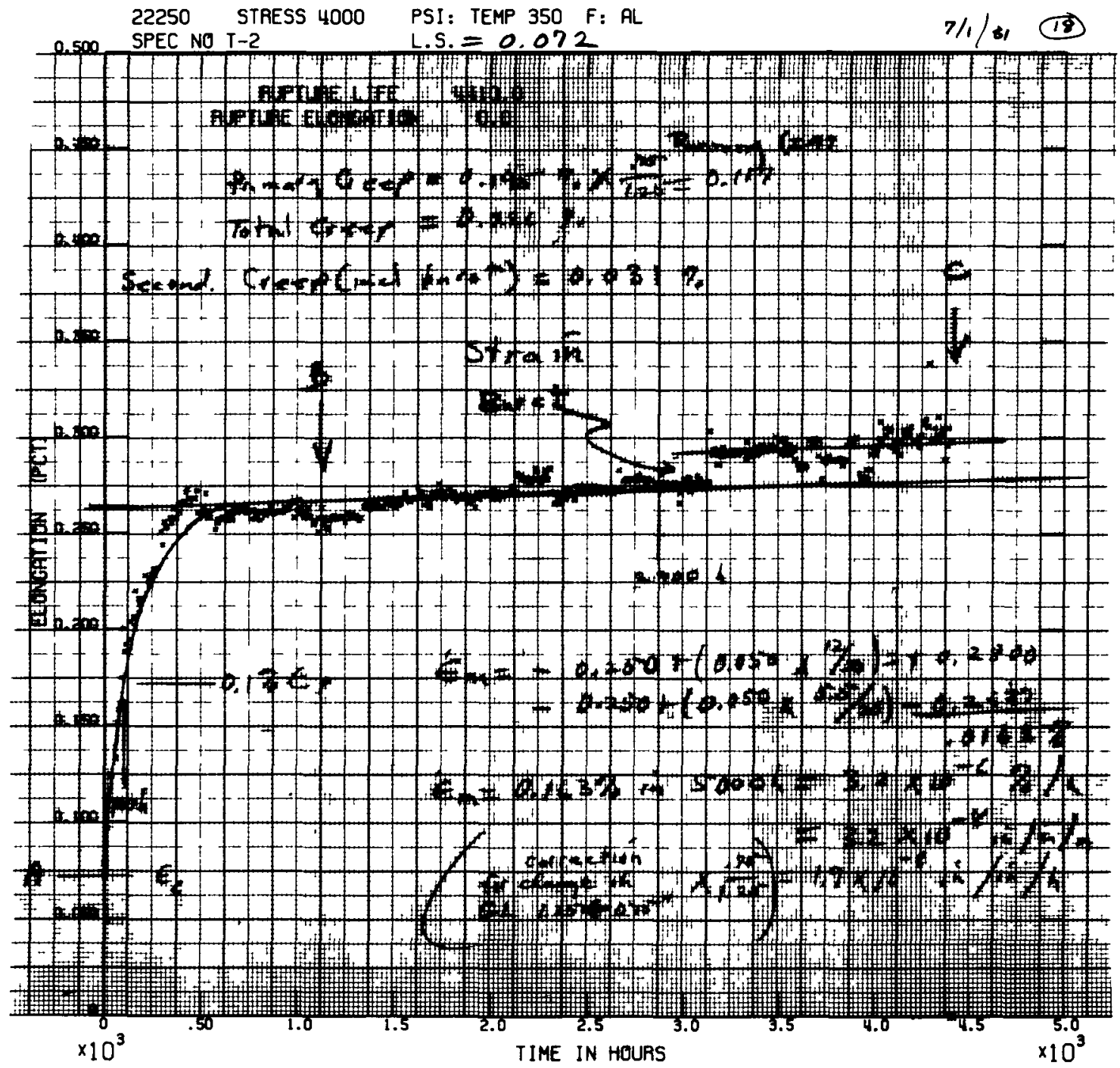




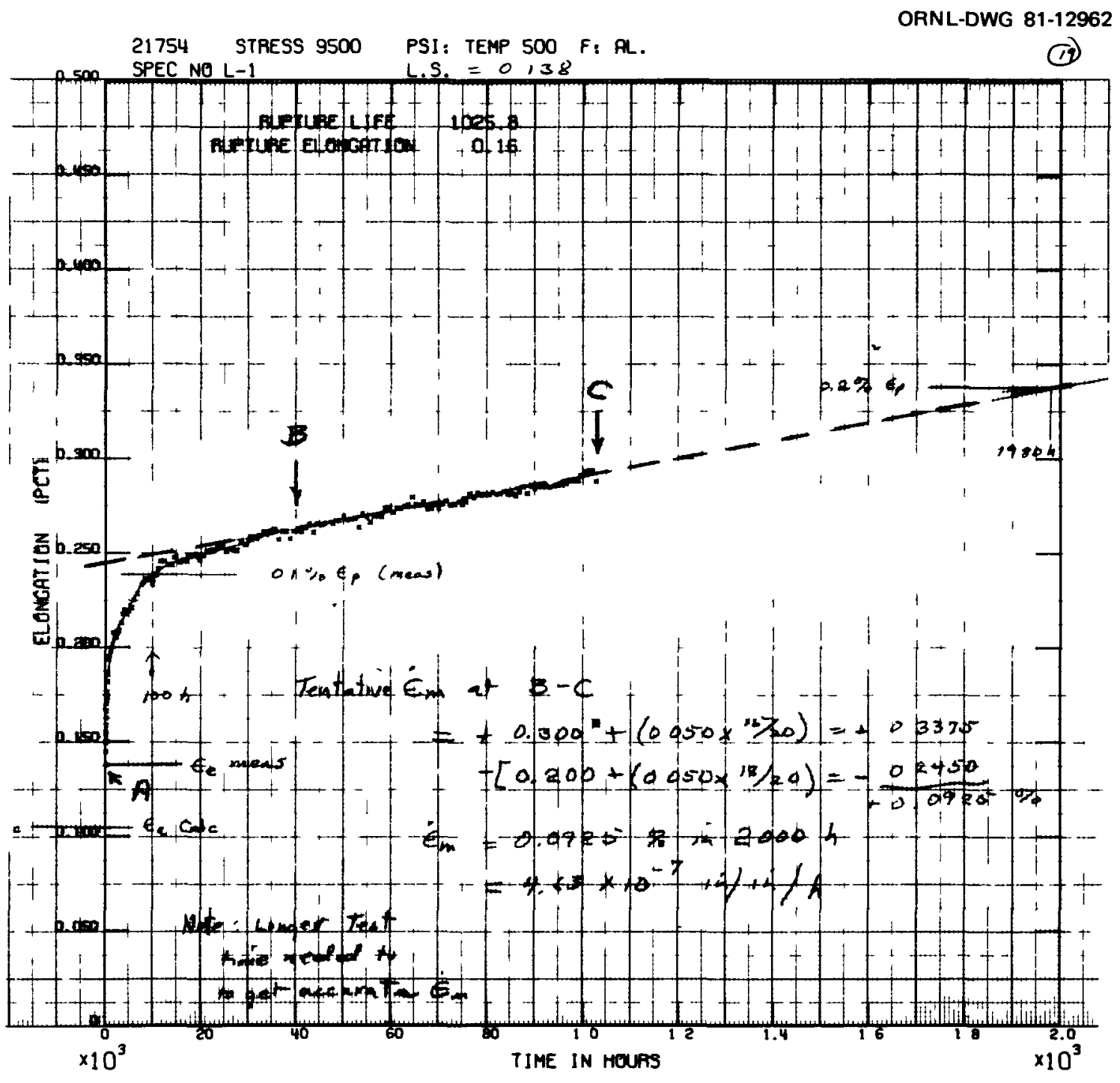


ORNL-DWG 81-12962

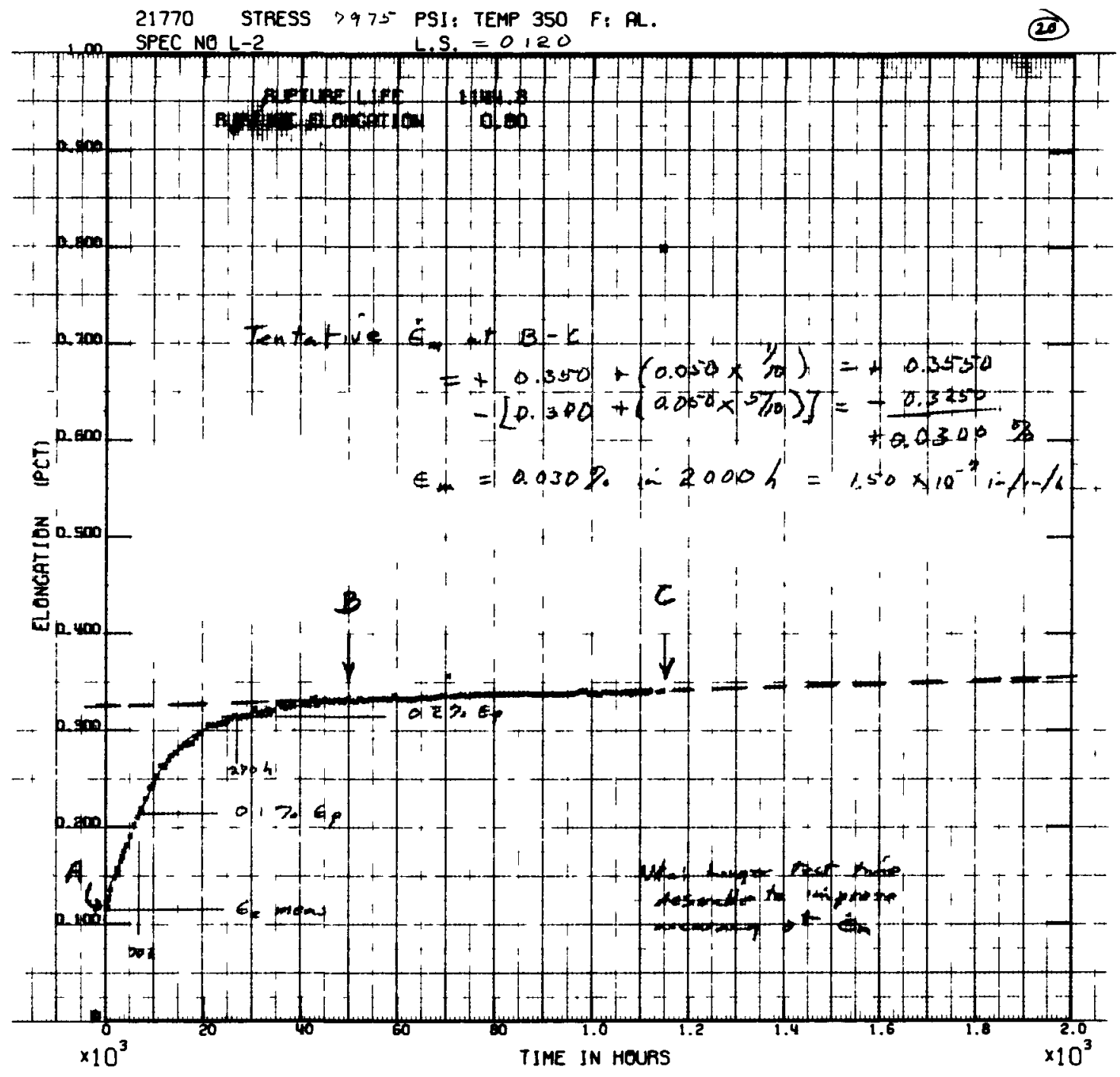


$4 x$

BLANK 
ORNL/TM-8020

\section{INTERNAL DISTRIBUTION}

1-2. Central Research Library
3. Document Reference Section
4-5. Laboratory Records Department
6. Laboratory Records, ORNL RC
7. E. E. Bloom
8. C. R. Brinkman
9. J. A. Carter
10. F. N. Case
11. R. H. Cooper
12. R. S. Crouse
13. J. E. Cunningham
14. S. A. David
15. J. H. DeVan
16. R. G. Donne1ly
17. W. P. Eatherly
18. J. I. Federer
19. B. E. Foster
20. G. M. Goodwin
21. K. W. Haff
2-26. J. P. Hammond
27. W. O. Harms
28. R. L. Heestand
21. M. R. Hill
32. H. Inouye
33. J. R. Keiser

34. R. L. Klueh

35. J. W. Koger

36. E. Lamb

37. C. T. Liu

38. M. M. Martin

39. D. L. McElroy

40. C. D. Montgomery

41. C. S. Morgan

42. T. K. Roche

43. A. C. Schaffhauser

44. C. S. Sims

45. G. M. Slaughter

46. J. 0. Stiegler

47. V. J. Tennery

48. D. B. Trauger

49. G. C. Wei

50. J. R. Weir, Jr.

51. C. L. White

52. A. L. Bement, Jr. (Consultant)

53. E. H. Kottcamp, Jr. (Consultant)

54. A. Lawley (Consultant)

55. T. B. Massalski (Consultant)

56. R. H. Redwine (Consultant)

57. K. M. Zwilsky (Consultant)

EXTERNAL DISTRIBUTION

58-70. DOE, SPACE AND TERRESTRIAL SYSTEMS DIVISION, Washington, DC 20545
G. L. Bennett
R. B. Morrow
R. C. Brouns
P. A. O'Riordan
F. E. Coffman
W. C. Remini
F. M. Dieringer
B. J. Rock
J. S. Griffo
W. F. Savage
W. D. Kenney
C. 0. Tarr
J. J. Lombardo

71-72. DOE, ALbUQUERQUE OPERATIONS OFFICE, P.O. Box 5400, Albuquerque, NM 87115
R. Clark
D. L. Krenz 
73-75. DOE, OAK RIDGE OPERATIONS OFFICE, P.O. BOX E, Oak Ridge, TN 37830

J. A. Lenhard

J. Pidkowicz

S. W. Ahrends

76. DOE, SAN FRANCISCO OPERATIONS OFFICE, 1333 Broadway, We1ls Fargo Building, Oakland, CA 94612

W. L. Von Flue

77. DOE, SAVANNAH RIVER OPERATIONS OFFICE, P.O. Box A, Aiken, SC 29801

L. C. Sjostrom

78. DOE, DAYTON AREA OFFICE, P.O. Box 66, Miamisburg, OH 45342

G. Gartrel1

79. AIR FORCE WEAPONS LABORATORY, Kirtland Air Force Base, DYUS, Albuquerque, NM 87116

Michael Seaton

80-81. BATTELle COLUMBUS labORATORIES, 505 King Ave., Columbus, OH 43201

E. L. Foster

I. M. Grinberg

82-83. E. I. DU PONT DE NEMOURS, Savannah River Plant, Aiken, SC 29801

D. C. Nichols

W. R. Kanne

L. P. Fernandez

84. E. I. DU PONT DE NEMOURS, Savannah River Laboratory, Aiken, SC 29801

R. L. Folger

85-86. FAIRCHILD INDUSTRIES, 20301 Century B1vd., Germantown, MD 20767

M. Eck

A. Schock

87-88. GENERAL ELECTRIC CO., Valley Forge Space Center, P.0. Box 8048, Philadelphia, PA 19101

R. J. Hemler

H. Dalal 
89. JOHN HOPKINS UNIVERSITY, Applied Physics Laboratory, Johns Hopkins Road, Laure1, MD 20810

J. C. Hagan

90. LOS ALAMOS NATIONAL SCIENTIFIC LABORATORY, P.O. BOX 1663, Los Alamos, NM 87545

S. E. Bronisz

91-92. MONSANTO RESEARCH CORP., P.O. Box 32, Miamisburg, OH 45342

W. Amos

E. W. Johnson

93. DOE, OAK RIDGE OPERATIONS OFFICE, P.O. BOX E, Oak Ridge, TN 37830 Office of Assistant Manager for Research and Development

94-120. DOE, TECHNICAL INFORMATION CENTER, P.O. Box 62, Oak Ridge, TN 37830 